\title{
Besturen op Europees niveau - lagen en listen, lusten en lasten
}

Citation for published version (APA):

Hoetjes, B. J. S. (2001). Besturen op Europees niveau - lagen en listen, lusten en lasten. Unigraphic. https://doi.org/10.26481/spe.20010209bh

Document status and date:

Published: 09/02/2001

DOI:

10.26481/spe.20010209bh

Document Version:

Publisher's PDF, also known as Version of record

\section{Please check the document version of this publication:}

- A submitted manuscript is the version of the article upon submission and before peer-review. There can be important differences between the submitted version and the official published version of record.

People interested in the research are advised to contact the author for the final version of the publication, or visit the DOI to the publisher's website.

- The final author version and the galley proof are versions of the publication after peer review.

- The final published version features the final layout of the paper including the volume, issue and page numbers.

Link to publication

\footnotetext{
General rights rights.

- You may freely distribute the URL identifying the publication in the public portal. please follow below link for the End User Agreement:

www.umlib.nl/taverne-license

Take down policy

If you believe that this document breaches copyright please contact us at:

repository@maastrichtuniversity.nl

providing details and we will investigate your claim.
}

Copyright and moral rights for the publications made accessible in the public portal are retained by the authors and/or other copyright owners and it is a condition of accessing publications that users recognise and abide by the legal requirements associated with these

- Users may download and print one copy of any publication from the public portal for the purpose of private study or research.

- You may not further distribute the material or use it for any profit-making activity or commercial gain

If the publication is distributed under the terms of Article $25 \mathrm{fa}$ of the Dutch Copyright Act, indicated by the "Taverne" license above, 


\title{
BESTUREN OP EUROPEES NIVEAU \\ lagen en listen, lusten en lasten.
}

\section{REDE}

Uitgesproken, in verkorte vorm, bij de aanvaarding van het ambt van Bijzonder hoogleraar regionaal bestuur in internationaal perspectief aan de Faculteit Rechtsgeleerdheid van de Universiteit Maastricht op vrijdag 9 februari 2001

\author{
door \\ dr. B.J.S. Hoetjes
}


(C) 2001, B.J.S. Hoetjes

ISBN 90-5681 095-2

De leerstoel is ingesteld door de Raad van Europese

Gemeenten en Regio's, sectie Nederland 
Mijnheer de rector magnificus, dames en heren,

In het midden van de jaren vijftig van de vorige eeuw - de eenentwintigste eeuw is nu echt begonnen - was het voor een jongetje uit de kop van Noord-Holland - of liever gezegd, Noord-Kennemerland - een bijzondere belevenis om de zomervakantie door te brengen in Hollandserading. Een verre reis, die per fiets werd afgelegd, en ons bracht in een andere wereld, in het Gooi. Het jaar daarop ging de reis naar Vilsteren, achter Ommen, en dat betekende niet alleen een fietstocht maar ook een echte zeereis van Amsterdam naar Kampen. Toen $i k$, weer een paar jaar later, de zomer in Spanje doorbracht, was dat zeer bijzonder - in mijn klas op het gymnasium was er, behalve ikzelf, welgeteld nog één leerling die de vakantie buiten Nederland had doorgebracht. Dat is nu wel anders: als vakantiebestemmingen vinden wij nu de Verenigde Staten, Canada, Zuid-Afrika, India, Nieuw-Zeeland, Italië of Griekenland heel gewoon. Onze geografische actieradius van mij, maar ook van de meesten hier in deze zaal - in de afgelopen decennia drastisch vergroot.

Ook in het werk wordt steeds gemakkelijker wereldwijd gecommuniceerd. Het contact en de samenwerking met mijn collega's in Duitsland, Frankrijk, Canada en de Verenigde Staten verloopt minstens even snel en effectief als met die in Groningen, Enschede of Amsterdlam - zeker wanneer er gecommuniceerd kan worden in het Engels, Frans, Duits of Nederlands. E-mail, fax, internet en mobiele telefonie hebben gezorgd voor een enorme sprong voorwaarts, in ieder geval kwantitatief. Ook het reizen wordt daardoor steeds gemakkelijker. Binnen Europa wordt dat bovendien door de invoering van de euro nog eenvoudiger dan het al was dankzij pinpas en creditcard.

Het wereldwijd werken wordt steeds meer gemeengoed, en het motto van het Nederlandse korps mariniers "Qua patet orbis" - zo wijd als de aardbol zich uitstrekt - lijkt werkelijkheid geworden.

Toch kunnen wij ons afvragen of deze geografische schaalvergroting ook gepaard is gegaan met een blikverwijding in mentale, sociale en culture zin. De duizenden Nederlanders, die jaarlijks naar Frankrijk of 
Spanje trekken, de caravan gevuld met de vertrouwde en voordelige Nederlandse levensmiddelen, of die per vliegtuig een zonnige plaats opzoeken "ergens achter Schiphol", gebruiken hun mobiele telefoon voor een regelmatig contact met de familie, of ingeval van problemen, voor het opbellen van het dichtstbijzijnde ANWB-steunpunt. Bovendien verblijft men vaak in een Nederlandse groep of in een Nederlandse toeristische enclave. Gemakkelijk en begrijpelijk, maar het betekent wel, dat het dankzij de communicatietechnologie niet meer nodig is om contact te leggen met mensen, die werkelijk anders zijn qua taal en gewoonten.

Daarnaast leidt het snelle, frequente contact via het scherm op zichzelf wel tot een snellere en meer uitgebreide informatievergaring, maar niet tot een verbreding of verdieping van de intermenselijke contacten. Virtuele contacten kunnen ondersteunend werken voor reële contacten, maar deze nooit vervangen. Sterker nog, zij kunnen zelfs storend werken - iemand, die nooit in levenden lijve langskomt, maar alleen maar e-mailt of telefoneert, zal zijn contacten op den duur zien verzwakken. Met behulp van de nieuwste communicatiemiddelen kunnen juist traditionele, bestaande bindingen worden versterkt. De Evangelische Omroep is daar een voorbeeld van, maar ook de informatieverschaffing over de Ramadan via het internet, of de emigranten-video's Nederlandse videos voor de Nederlanders in Australië, Turkse en Marokkaanse video's in Nederland. Het is dus maar zeer de vraag, of de vergroting van onze actieradius meer betekenis heeft dan een louter geografische, dat wil zeggen het afleggen van meer kilo-meters op deze aardbol. Al dat gereis, waartoe leidt dat eigenlijk? Zijn wij steeds meer wereldburger aan het worden (1), Europeaan misschien, of blijven wij vooral gericht op onze familie, onze plaatselijke gemeenschap of onze "nationaliteit'?

De belangrijkste vraag is daarbij, met wie wij ons het meest verbonden voelen - is die kring van sociale, intermenselijke bindingen groter geworden, gelijk gebleven of misschien zelfs verkleind?

Deze vragen spelen ook in het openbaar bestuur en de politiek. Ook daar hebben communicatie, mobiliteit en schaalvergroting hun doorwerking. Volgens sommige bestuurskundigen (2) en bestuurders is de 
geografische indeling in ons openbaar bestuur - gemeenten, provincies, rijk, Europa, wereld - door de nieuwe communicatietechnologie achterhaald. Zo voorziet minister van Boxtel, dat de dienstverlening door de overheid an de burger via het scherm en de telefoon tot een volstrekte doorbreking van de gevestigde indelingen zal leiden - zijn ministersportefeuille, van Grote Stedenbeleid en Minderheden kan nu inderdaad worden aangeduid als de portefeuille van GSM.

Dan is er het wegvallen van de landsgrenzen: de afschaffing van de grenscontroles en straks de invoering van de euro levert voor de burgers, maar ook voor overheden een enorme vergroting van mogelijkheden om zaken te doen en contacten te leggen. Mobiliteit en keuzevrijheid worden zo groot, dat men zich kan afvragen, in hoeverre Nederland nog wel bestaat, anders dan in geografische zin. De Nederlandse taal en het Nederlandse rechtsstelsel mogen dan herkenbaar 'Nederlands' zijn, maar het gedrag en de manier van leven van de Nederlanders is vooral 'internationaal' - ons voedsel, onze kleding, onze cultuur. Wat is eigenlijk 'zuiver Nederlands'?

Toch is het opmerkelijk, dat juist tegen deze achtergrond van 'globalisering' binnen de sociale wetenschappen in Nederland de vraag naar de eigen, nationale identiteit nadrukkelijk in de belangstelling is gekomen (3). Een onderwerp, dat tot in de jaren ' 70 taboe was vanwege de associatie met het begrip 'volkskarakter' en andere narigheid uit de periode 1933-1945. Globalisering roept kennelijk tegenkrachten op, geheel in de lijn van de dialectiek van Hegel en Marx.

Wij zien dit ook bij de gehechtheid van mensen aan hun directe, plaatselijke omgeving. Bij gemeentelijke herindelingen worden vaak grote emoties losgemaakt, niet alleen in kleine dorpsgemeenschappen, die zich in hun identiteit bedreigd voelen, maar ook in stadsgebieden zoals Den Haag en omstreken. Bestuurlijke schaalvergroting wordt gevoeld als een schending, een gebrek aan respect voor vertrouwde verbanden, waar men zich thuis voelt. Daarbij wil ik u niet het voorbeeld onthouden van de mevrouw uit Leidschendam, die haar hart luchtte over de herindelingsplannen in het programma van Radio-west 'het gesprek van de dag' - na het nieuws van zes uur, ik luister er nog wel eens naar, ook al vind ik het vaak 'het gezwets van de dag'. Zij was zeer 
verdrietig en emotioneel over de woorgenomen overgang van haar woonwijk en haar straat naar de gemeente Den Haag, maar ze zei 'ik kan er toch niets aan doen, dus laat maar, ik ben allang blij, dat ik in mijn huisje mag blijven wonen en niet weghoef. Een gevoel van machteloosheid, van afhankelijkheid en een afkeer van politiek en bestuur. Men trekt zich terug in de privé-sfeer van het eigen huis, familie en gezin - "my home is my castle". Bestuurlijke schaalvergroting kan bij de burger oproepen een gevoel van vervreemding, en een neiging tot schaalverkleining van de kring, waarmee hij zich verbonden woelt.

Een andere politieke en bestuurlijke kant van schaalvergroting, mobiliteit en communicatie-ICT is, dat niet alleen de keuzemogelijkheden, informatiebronnen en contactmogelijkheden worden vergroot, maar ook de mogelijkheden voor controle. Telefoonverkeer kan worden afgeluisterd, zowel binnenlands als internationaal, faxverkeer, e-mail en internetgebruik laten zich gemakkelijk traceren en registreren door werkgevers, overheidsinstanties of commercieel geïnteresseerden. Sofinummer en postcode, financiële gegevens, medische gegevens en verzekeringsgegevens - de technische mogelijkheden voor indringende observatie en controle, al dan niet via combinatie van bestanden, zijn enorm. 1984, het jaar van George Orwell's technologische heilstaat, ligt alweer jaren achter ons, maar dat wil niet zeggen, dat 'big brother is no longer watching you'.

Wij worden dus ook in bestuur en politiek geconfronteerd met de vraag, welke bindingen, belangen en loyaliteiten meespelen, welke het meest doorslaggevend zijn, en hoe deze in de afgelopen decennia zijn veranderd, onder invloed van schaalvergroting in internationaal verband.

Wij spitsen deze vraag, in het vervolg van deze beschouwing, toe op onze/uw ongeving: welke betekenis heeft de Europeanisering gehad voor de manier waarop wij worden bestuurd? Nog preciezer is onze vraag: welke betekenis heeft de ontwikkeling van de Europese bestuurslaag gehad voor het bestuurlijke en politieke systeem als geheel? 
Om deze vraag aan te vatten, kunnen wij drie verschillende wegen bewandelen, die ik kort zal aanduiden - en wij zullen kiezen (u raadt het al) voor de Derde Weg.

De eerste weg zou kunnen zijn: het uitgangspunt van de concentrische cirkels. Met het individu als middelpunt, kan men een opbouw zien van kringen: de familiekring, de plaatselijke gemeenschap, de werkkring, en zo steeds groter, tot en met de Europese kring of de kring van wereldburgers. Elke kring kent zijn eigen karakter, maar is ook opgenomen in een groter geheel. Elke kring moet zijn 'soevereiniteit in eigen kring' koppelen aan de rechten en plichten in groter verband. Het is, inderdaad, een gedachtegang die in protestants-christelijke kring (sic), bij de politicologen aan de Vrije Universiteit veel ingang heeft gevonden (4).

De tweede weg zou kunnen zijn: de politiek-fillosofische uitgangspunten van het subsidiariteitsdenken en het federalisme. Subsidiariteitsdenken is geworteld in de politieke filosofie van Thomas van Aquino uit de twaalfde eeuw (5), en geniet momenteel veel aanzien in de EU - het is daar zelfs als besluitvormingsbeginsel vastgelegd. Federalisme heeft iets minder oude wortels - de zestiende-eeuwse filosoof Johannes Althusius (6) -, maar gold tot voor kort als grote inspiratiebron voor de Europese eenwording. Sinds de banvloek van mevrouw Thatcher, die het tot 'F-word' verklaarde, en sinds de stille vrees voor het Duitse federale model in de EU, is het begrip wat op de achtergrond geraakt.

Ik heb daarom gekozen voor een derde weg, namelijk die van een culinaire metafoor, een beeldspraak uit de keuken: Europa als lagentaart. Waarom deze keus?

Allereerst natuurlijk, omdat ik meen, dat deze beeldspraak ons verder helpt bij het verhelderen van onze gedachten, het signaleren van problemen en het opdoen van nieuwe ideeën. Het is uiteraard aan u om, na afloop van deze beschouwing, te beoordelen of $u$ dat ook vindt.

Daarnaast is het zo, dat culinaire beelden de fantasie prikkelen - wie voelt zich niet aangesproken door het beeld van een goed verzorgde maaltijd en een lekker, zorgvuldig klaargemaakt gerecht? 
Bij het onderzoek naar Europese integratie en Europese besluitvorming is bovendien de culinaire metafoor niet ongebruikelijk. Zo ziet men bij de analyse van de EU-besluitvorming het beeld van de soep (Ursuppe, primeval soup)(7) die moet worden gekookt. Het gaat er dan om, de juiste ingrediënten bij elkaar te brengen, het geheel aan de kook te brengen en - vooral - aan de kook te houden. Een volhardende pleitcoalitie, die een zaak in de aandacht houdt, is voor dat laatste essentieel (8).

Wij gebruiken hier het beeld van een lagenmaat, een layer cake (9).

In Nederlandse termen zou u kunnen denken aan een spekkoek, een koek die overigens van Indonesische oorsprong is. Het vervaardigen van een spekkoek is een geduldwerkje: stap voor stap, laag voor laag wordt er een nieuw laagje aangebracht, in de oven gezet, na een korte tijd weer uit de oven gehaald, nieuw laagje aanbrengen, weer in de oven etc. etc. Het resultaat is een dikke taart met vele laagjes, die erg lekker smaakt (speculaaskruiden) - een beloning voor een langdurig, voorzichtig en zorgvuldig werk.

Nu moet ik erbij zeggen: wanneer we naar de Europese bestuurlijke verhoudingen kijken, dan is dat geen gewone spekkoek, maar een heel bijzondere. Wat eigenlijk is gebeurd, is het bij elkaar zetten van een aantal taartpunten - de lidstaten - die al een eigen lagenstructuur hadden, en wel heel verschillende lagenindelingen. Nederland kent drie bestuurslagen, België vier, Duitsland en Frankrijk vijf. Bij elkaar gezet in een bakvorm, is over dit geheel een gezamenlijke bovenlaag aangebracht, en vervolgens is het in de oven gezet. In 1952 is proefgedraaid met de Europese Kolen- en Staalgemeenschap, en in 1957 werd het menens met de verdragen van Rome (EEG-Euratom). $\mathrm{Nu}$, ruim veertig jaar later, is volgens sommigen Europa 'af" - het was dhr. Bolkestein, die dat stelde, enige tijd voordat hij de Nederlandse politiek verliet om Eurocommissaris te worden in Brussel. Of Europa inderdaad af is en de lagentaart in de oven gaar en klaar, weet ik niet zeker - of liever gezegd, ik weet wel zeker, dat dat niet zo is.

Ik ga dan ook met u door het venster van de oven kijken: hoe zien die verschillende lagen eruit, en wat gebeurt er allemaal door het aanbrengen van de Europese bovenlaag? 
Eerste vraag is dan: wat zijn de kenmerken van de verschillende bestuurslagen en hun eigenaardigheden? Wij beginnen boven, bij de Europese laag. Overigens noemen wij hier het lokale bestuur de eerste bestuurslaag - die berust op de 'bodem', dat wil zeggen de samenleving, de economie, de 'civil society'. Vanuit Nederlands perspectief is de $\mathrm{EU}$ dus de vierde.

Op EU-niveau bestaat een bestuurslaag - dat zal nog maar door weinigen worden ontkend. Weliswaar bestaat er geen Europese Staat met een Regering en een compleet eigen afdwingingsapparaat, maar heeft zich sinds 1957 wel een geheel van instellingen en procedures ontwikkeld, die op EU-niveau beleid produceren (10). Dat beleid houdt, in zeer algemene zin, in, dat er voor gemeenschappelijke problemen gemeenschappelijke oplossingen worden afgesproken, die worden neergelegd in hetzij bindende regelgeving, hetzij onderlinge beleidsafspraken. Bovendien houdt EU-beleid vaak ook in, dat er geld wordt overgedragen (subsidies, heffingen, afdrachten etc.). EU-belleid bemoeit zich thans in feite met alle terreinen van overheidsbeleid, en het wordt ook nog uitgevoerd, nageleefd en gecontroleerd.

De EU-bestuurslaag is na de Tweede Wereldoorlog ontstaan uit verschillende ingrediënten: desillusie, angst, vernieuwingsdrang, idealisme en bureaucratie. Druk van buitenaf speelde daarbij een zeer belangrijke rol. Desillusie, om niet te zeggen wanhoop, over de ellende die door twee wereldoorlogen over dit continent was uitgestort - menselijk, economisch, maar ook moreel en politiek. De ontreddering van die tijd kunt u zich nog het beste voorstellen, wanneer u de televisiebeelden ziet van de oorlog in voormalig Joegoslavië en de huidige toestand daar. Het was een tijd van wanhoop - niet toevallig zijn vele duizenden Europeanen in die tijd geëmigreerd naar andere werelddelen - en volledig politiek diskrediet van de nationale staat, als bron van oorlog. Zoals François Mitterand eens zei: 'le nationalisme c'est la guerre' - en dat uit de mond van een Fransman. Angst voor een nieuwe oorlog, angst voor het oprukkende communisme - 'de Russen komen eraan' (inmiddels zijn zij inderdaad aangekomen, maar dan niet per tank, maar per auto..) dreef de landen van West-Europa tot samen- 
werking. Amerikaanse druk, politiek en economisch (de Marshallhulp) deed daarbij ook zijn werk. Er moest een nieuw Europa komen, een United States of Europe, samenwerkend in het gezamenlijk Europees belang, en daarvoor werden nieuwe instellingen gevormd, waarin de beste deskundigen de kern zouden vormen van een Europees bestuur. Een visionaire en missionaire bureaucratie, een 'bureaucratie de mission" naar Frans model, moest de motor van het nieuwe Europa worden, waarin nationale belangen ondergeschikt zouden worden aan het Europese belang.

De Europese bestuurslaag is dan ook, vergeleken met de andere bestuurslagen, jong - bijna vijftig jaar, wanneer wij de Europese Kolenen Staalgemeenschap (1952) als startpunt nemen -, vervuld van Europese zendingsdrang - ik bedoel daar niets negatiefs mee - en, mede daarom, voortdurend op zoek naar nieuwe mogelijkheden. Met name de Europese Commissie kan men aanduiden als een 'ondernemende bureaucratie'(11), die voortdurend, ondanks tegenslagen en problemen, zoekt naar nieuwe kansen voor Europees beleid. Het is bovendien een relatief kleine bureaucratie, multi-cultureel bij uitstek, en zeer open tegenover invloeden van buitenaf - volgens sommigen misschien wel té open (12) - Daarbij moet echter wel worden aangetekend, dat bij de EU-beleidsvorming de Commissie niet de enige speler is.

Gaandeweg hebben de Raden van Ministers en de Europese Raad een steeds grotere, en in feite doorslaggevende, rol gekregen in de besluitvorming. In deze Raden(13) zitten de vertegenwoordigers van de regeringen van de lidstaten bij elkaar en proberen daar at of niet tot overeenstemming te komen. Vervolgens klinkt dan het verwijt op, dat zij alleen maar de nationale belangen najagen - ja, dat haal je de koekoek. Wanneer de nationale eigenbelangen bij elkaar worden gezet, dan komt daar natuurlijk niet vanzelf een gemeenschappelijk Europees belang uit voort. De BSE-kwestie bijvoorbeeld heeft duidelijk laten zien, dat er een supranationale instantie nodig is om beslissingen door te zetten, waarvan iedereen weet, dat ze nodig en juist zijn, maar die politiek onverkoopbaar zijn voor de afzonderlijke nationale regerin- 
gen. Voor effectieve EU-besluitvorming zijn supranationaliteit en solidariteit onmisbaar.

Het is in feite verbazend, dat door de jaren heen, temidden van een groeiend intergoevernementalisme, zich toch de zgn. communautaire methode heeft kunnen ontwikkelen - bij de Commissie, maar ook tot op zekere hoogte bij de Raden -, die het mogelijk maakt om boven de nationale belangen uit te komen. Deze methode omvat een aantal spelregels: het streven naar consensus, een oververtegenwoordiging van de kleinere lidstaten, de bereidheid van de afzonderlijke lidstaten om zich te laten overstemmen door de anderen, mits er op de lange duur geen 'structurele verliezers' ontstaan. Er moet voor iedere lidstaat uiteindelijk iets te winnen zijn.

Deze methode is kenmerkend voor het EU-besluitvormingsproces. Er zijn ook andere typische kenmerken (15). Ik noem het hoog-bureaucratische karakter, dat is de neiging om problemen op te lossen door verfijning en verdikking van regels, waardoor uiteindelijk de zaken vastlopen en informele 'shortcuts' worden uitgelokt. Ik noem ook het tekort aan democratische verantwoording. Hoewel, vergeleken met bijvoorbeeld de Verenigde Naties of de NAVO, de rol van het Europese Parlement aanzienlijk is, valt de vergelijking met de nationale parlementen toch negatief uit. Democratische openheid en verantwoording op EU-niveau schieten nog steeds tekort.

De productiviteit van de Europese bestuurslaag is opmerkelijk hoog. Momenteel produceert de EU jaarlijks evenveel richtlijnen en verordeningen als een nationale overheid (bijvoorbeeld meer dan Parijs - een regering die toch niet bekend staat om haar lage wetgevingsproductie). Het acquis, dat is alle EU-regelgeving opgebouwd over de afgelopen decennia, groeit alleen maar verder en wordt soms met grote sprongen uitgebouwd, zoals bijvoorbeeld door de opname van het verdrag van Schengen. Ook de naleving van de EU-regelgeving is opmerkelijk hoog en kan de vergelijking met nationale of gemeentelijke regegeving volledig doorstaan - zeker wanneer ik in Nederland zie, hoe de regel 'een fietser mag niet door een rood stoplicht rijden' wordt nageleefd, of liever gezegd wordt genegeerd. In de jaren '70 hadden we het verschijnsel 'tien over rood', momenteel is het 'tien door rood'. 
Naleving van EU-regels werkt volgens de formule: "uitbesteding aan de nationale, regionale of lokale overheden, toezicht door de Europese Commissie en afdwinging via het Europese Hof'. Dat is een redelijk geslaagde formule - zo u wilt, een Europese list om naleving te bereiken door mee te liften met de afdwingingsmacht van de lidstaten (16). Toch is het bij de Europese bestuurslagen wel de vraag, hoe het staat met de politieke steun onder de burgers - wie is de Europese achterban? Toen de Belgische koning ten tijde van de taalstrijd zijn volk wilde toespreken en aan zijn adviseurs vroeg, hoe hij dat het beste zou kunnen doen, sprak een wijs adviseur de gedenkwaardige woorden 'sire, il n'y a pas de belges' - majesteit, er zijn geen Belgen, alleen maar Vlamingen en Walen. België bestaat nog steeds, en wordt hier in Nederland systematisch onderschat in politiek en economisch opzicht, maar dit terzijde.

Wanneer de heer Prodi als voorzitter van de Europese Commissie 'zijn' volk zou willen toespreken, zou men hem eigenlijk ook moeten voorhouden: 'monsignore, il n'y pas d'Européens'. Binnen Europa zijn er geen Europeanen. Wanneer u op straat of in een café iemand zou vragen 'waar komt $u$ vandaan?', dan kunt u allerlei verschillende antwoorden verwachten, maar de kans dat iemand zou antwoorden 'ik kom uit Europa' is zeer klein. De verbondenheid van mensen met 'Europa' kan wel bestaan, maar andere bindingen - met de woonplaats, met de nationale staat, met de regio - zijn sterker. Een onderzoek naar de publieke opinie over de EU - binnenkort afgerond binnen de capaciteitsgroep Metajuridica hier aan de Faculteit, jawel laat duidelijk zien, dat de steun van burgers aan de Europese integratie altijd gekoppeld is aan de meningen van nationale elites. Met andere woorden, de politieke steun en loyaliteit aan de EU is altijd ingebed in, en meestal zwakker dan, de steun voor de nationale staat. De EU-bestuurslaag kent geen brede en diepe, echt Europese, publieke discussie over de gezamenlijke Europese beleidsproblemen. Dat is een probleem vanuit het oogpunt van democratische openheid en verantwoording, er zou iets aan gedaan moeten worden - maar het is wel een feit dat wij onder ogen moeten zien. 
De nationale bestuurslaag, vervolgens - de derde bestuurslaag. Zoals wij zojuist zagen, was na 1945 de nationale staat emstig in diskrediet geraakt. Nationalisme - het ideologisch vergoddelijken van de nationale staat - had niet alleen tot verdeling en tegenstelling in Europa geleid, maar ook, herhaalde malen, tot grootscheepse verwoesting en collectieve zelfdestructie (17).

Het oorlogspotentieel van de nationale staat in Europa - zowel de winnaars als de verliezers - moest daarom onder controle worden gebracht - en, paradoxaal genoeg, tegelijkertijd ook weer worden opgebouwd om de dreiging van het communisme te weerstaan. Dat gebeurde, maar grotendeels buiten het Europese kader - het transatlantische bondgenootschap werd voor de meeste landen in West-Europa het onderdak, dat de militaire veiligheid moest waarborgen. De NAVO was/is intergoevernementeel van opzet, en respecteerde/respecteert de nationale soevereiniteit op militair terrein. Wel merk ik op, dat er een serieuze poging werd gedaan om de strategische industrie - de zware industrie - van een aantal landen onder supranationaal Europees gezag te brengen: de Kolen- en Staalgemeenschap. Weldra bleek echter, dat de bereidheid om zich aan supranationale beslissingen te onderwerpen het moest afleggen tegen nationale belangen. De zachte winter van 1959 leidde tot de ineenstorting van de steenkolenprijs, en van de EGKS - zachte winters kunnen harde politieke consequenties hebben.

Ondanks het politieke diskrediet van de nationale staat zien wij in de jaren ' 50 , de jaren van de wederopbouw, een opmerkelijk terugkeer van nationale politieke partijen en overheidsinstellingen. 'Nederland herrijst' kunnen wij lezen op de talloze herdenkingstegels en -borden die in die tijd zijn gemaakt. Eigenlijk zijn in Europa alle nationale staten herrezen, en de wederopbouw van de jaren '50 was meer een kwestie van restauratie dan van renovatie. Alleen in Duitsland werd de staatsstructuur drastisch vernieuwd en vooral van Pruisische elementen ontdaan - entpreusst. Sommige afzonderlijke staten gingen zelfs nog weer op oorlogspad - Nederland en Frankrijk in koloniale oorlogen, Frankrijk en Groot-Brittannië in de Suez-crisis -, maar hebben daar hoegenaamd geen succes weten te boeken. Sinds de jaren '70 hebben alleen Portugal en Groot-Brittannië - in Afrika resp. de Falklands - 
nog een 'eigen', nationale oorlog gevoerd - eveneens met weinig succes. Het militaire potentieel van de afzonderlijke nationale staten in West-Europa kunnen wij dan ook aanduiden als 'duidelijk afgenomen'.

De vraag is mu, of dat ook geldt voor het politieke potentieel van de nationale staat in Europa, en dan is het antwoord heel anders. Sinds de Tweede Wereldoorlog is in de meeste landen van West-Europa de nationale staat 'gezuiverd', d.w.z. politiek ongewenst personeel werd uit openbare ambten verwijderd en vervangen. In sommige landen is de nationale staat ook ernstig verzwakt, in crisis geraakt en vervolgens van een nieuwe grondwet voorzien. U kunt dan denken aan Frankrijk met zijn vijfde Republiek, België met haar federalisering, maar ook aan Griekenland, Spanje en Portugal met hun uiteindelijke stelselwijzigingen in de jaren '70.

Dat waren op zich genomen allemaal belangrijke veranderingen, maar het waren ook een paar dingen niet. Het waren wel politieke stelselwijzigingen, maar bestuurlijk bleef het bestaande raamwerk intact het zou zeer veel tijd en grote moeite kosten, om ook de bestuursstructuur te veranderen, en in de meeste gevallen is dat tot de dag van vandaag nog verre van voltooid. Politici komen en gaan, de overheidsbureaucratie blijft bestaan. Deze veranderingen van politiek stelsel betekenden bovendien niet, dat de nationale staat, en de nationale identiteit, als zodanig ter discussie werden gesteld. Met uitzondering misschien van België, werd de vraag 'bestaan wij eigenlijk wel als nationale staat?' in feite nergens in Europa gesteld, en impliciet met een aanhoudend 'ja' beantwoord. Het begrip 'nationaal belang' en 'nationale identiteit' is anno 2001 nog steeds politiek correct, in Nederland is het zelfs recentelijk weer in ere hersteld - of misschien moeten wij zeggen, uit de politieke mottenballen gehaald. Fundamentele bestrijders van een nationaal staatsverband - in Groot-Brittannië, Spanje - bevinden zich in politiek extreem, en vaak gewelddadig, vaarwater. Overigens is het interessant om te zien, hoe in deze beide gevallen het EU-niveau op de achtergrond een bemiddelende rol kan spelen, zij het dat succes niet is gegarandeerd.. 
In de politieke en bestuurlijke hoofdstroom in Europa heeft de nationale staat een volledige come-back gemaakt, ook al is het volgens sommigen een lekkende boot. De nationale staat heeft immers geen volledige greep op allerlei maatschappelijke ontwikkelingen en ziet zowel internationaal als binnenlands zeer veel zaken uit zijn handen glippen. Het feitelijke vermogen van de nationale staat om aan de burgers datgene te verschaffen, wat zij eisen en verwachten, is verre van volledig - de problematiek van de voedselveiligheid is maar éen van de vele voorbeelden. Niettemin: de politieke loyaliteit, politieke aandacht en politieke discussie in Europa en ook de bestuurlijke activiteit en loyaliteit - beleidsvorming, beleidsuitvoering - zijn bij uitstek nationaal gebleven. Kennelijk voldoet de nationale staat nog steeds als kader, waarbinnen burgers zich thuisvoelen - zeker wanneer het min of meer samenvalt met taal en cultuur -, waarbinnen men het gezag van de overheid erkent, en waarbinnen men discussieert en de degens kruist over allerlei problemen waaraan 'iets gedaan moet worden'. 'lets doen' betekent in de praktijk, dat de nationale overheid beleid moet formuleren, en dat de nationale overheidsbureaucratie, gehoorzaamd wordt - en niet bijvoorbeeld een Europese overheidsbureaucratie. Het zwaartepunt van bestuur en van politiek - en dan denk ik ook aan de media, de politieke partijen - ligt op het nationale niveau. Vooral in landen met een lange geschiedenis van centralisme en van nationale glorie - Frankrijk, Groot-Brittannië - kan dat gemakkelijk leiden tot een politiek autarkie-denken - de stilzwijgende gedachte, dat alles, wat de moeite waard is, in eigen land gebeurt of daarmee direct verband houdt, plus de neiging om ingeval van problemen zich af te keren van de boze buitenwereld en de oplossingen geheel 'in eigen huis' te zoeken. De besluitvorming rond de gekke-koeien-ziekte heeft daarvan interessante staaltjes laten zien.

Er zijn niettemin nogal wat politieke en bestuurlijke verschijnselen en veranderingen, die zich Europa-breed hebben voorgedaan in de afgelopen vijftig jaar. U kunt denken aan de economische wederopbouw, de groei van de verzorgingsstaat, de democratiseringsgolf van de jaren '60 en '70 (van de Nederlandse Maagdenhuisbezetting tot de omwentelingen in Spanje en Portugal), de terugtredende overheid in de jaren 
' 80 , het marktdenken van de jaren ' 90 - of ook aan het bestaan van politieke stromingen over de landsgrenzen heen (sociaal-democratisch, liberaal, christen-democratisch) of aan de problemen van economie, miliew, veiligheid en migratie, die overal in de politieke aandacht staan. Toch manifesteren zij zich allemaal in het nationale kader - hoe geforceerd of onzinnig dat soms ook lijkt, of is.

Daarbij is het interessant om op te merken, dat de nationale staat weliswaar ouder is dan de Europese bestuurslaag, maar toch minder oud dan wel eens wordt gesuggereerd. Als nationaal staatsverband dateren België en Griekenland uit de eerste helft van de negentiende eeuw, Duitsland en Italië uit de tweede helft van de negentiende eeuw - met voor Griekenland en Duitsland nogal wat gebiedsveranderingen sinds hun ontstaan -, Zweden in de huidige vorm uit het begin van de twintigste eeuw - na de Noorse afscheiding -, Oostenrijk en Ierland uit de jaren na de eerste wereldoorlog - ieder met een geheel eigen historische achtergrond en verschillende ontwikkeling nadien. In vrijwel ieder land in Europa laat de geschiedenis een sterke dynamiek zien. Ook al zijn vele nationale staten in Europa eeuwenoud - of tenminste een eeuw -, dat geeft hun nog geen eeuwigheidswaarde. Wij komen dalar straks op terug.

Het niveau van het tussenbestuur, de tweede bestuurslaag, betekent vanaf deze plaats: de provincie (18). In Nederland was de provincie de historische bouwsteen van het staatsbestel, de Republiek der Verenigde Nederlanden uit 1648. De Republiek was politiek en bestuurlijk geen succes - zacht uitgedrukt - en in 1795 werd in de Bataafse Republiek van ganser harte een nieuw, centraal stelsel naar Frans model omarmd. Niettemin werd in de grondwet van 1848 de provincie als democratisch-politiek tussenniveau, met zelfstandige bevoegdheden, in ere hersteld, zij het met een duidelijke inkadering in de gedecentraliseerde eenheidsstaat, via de medebewindstaken en via de verantwoordelijkheden van de Commissaris van de Koningin. Een herinnering aan de oude Republiek is nog het optreden van de Provinciale Staten als college van 'kiesmannen' voor de verkiezing van de Eerste Kamer. De provinciale bevoegdheden hebben zich in de praktijk 
vooral ontwikkeld als toezichthoudend, coördinerend en verdelend, als tussenbestuur tussen nationale en gemeentelijke overheid.

Daarmee werd het provinciaal bestuur minder zichtbaar voor de burgers, en is daardoor gemakkelijk te onderschatten - door de burgers; maar ook door de provinciebestuurders zelf. Op sommige terreinen heeft de provincie haar bevoegdheden actief benut (bijvoorbeeld in milieubeleid), op andere terreinen is dat niet gebeurd, en wordt zij node gemist. De ernstige problemen in Nederland op het gebied van de ruimtelijke ordening en de infrastructuur, bijvoorbeeld, kunnen voor een belangrijk deel worden toegeschreven aan de bestuurlijke afwezigheid van de provincies - als buffer, coördinator en afweger. Ook politiek gezien is de provincie wat op de achtergrond geraakt, maar is om verschillende redenen toch interessant. Bijvoorbeeld omdat er soms in de provincie regeringscoalities - 'paars', bijwoorbeeld - worden uitgeprobeerd, die later op national niveau naar voren komen. Bijvoorbeeld ook, omdat er in sommige provincies - bijvoorbeeld Limburg, maar ook enige andere - een sterke culturele en regionale identiteit bestaat, die aanleiding geeft tot een actieve en effectieve bestuurlijke opstelling. Recentelijk heb ik hierover een publicatie uitgebracht, waarnaar ik de belangstellende lezers graag verwijs. Politieke identiteit kennen de Nederlandse provincies nauwelijks - alleen in Friesland bestaat een specifiek Friese politieke partij.

In andere lidstaten van de EU ligt dit heel anders (19). Het tussenbestuur in België, Duitsland en Oostenrijk - alle drie federale stelsels bezit uitgebreide bevoegdheden, gebruikt die ook volop en kent een actief politiek-democratisch en bestuurlijk leven. Vaak berust het tussenbestuur op aanmerkelijke regionale verschillen in economisch, sociaal, cultureel en politiek opzicht. In Spanje en Italië hebben deze verschillen - op verschillende wijze - doorgewerkt en geleid tot grondwetswijzigingen waarbij sterke bevoegdheidsoverdrachten plaats-vonden naar de autonome gemeenschappen (Spanje) en de regio's (Italië) - zonder dat evenwel een federaal stelsel ontstond. In landen met een centralistische traditie (Frankrijk, Groot-Brittannië) zien wij ook het tussenbestuur in belang toenemen, maar dan wel op een nogal aarzelende manier. De vraag, waar precies het tussenbestuur ligt, wordt 
trouwens in iedere lidstaat anders beantwoord. Bovendien ziet men binnen diverse lidstaten, dat de positie van sommige tussen-besturen (regio's, bijvoorbeeld) anders is geregeld dan die van andere - dat geldt zowel in Groot-Brittannië als in Spanje of Italië. Als ergens de bestuurlijke varieteit binnen de EU naar voren komt, dan is het wel op het niveau van het tussenbestuur. Dat leidt tot nieuwe mogelijkheden en problemen in EU-verband, waarop wij zo dadelijk terugkomen.

Dan is er tenslotte de onderste bestuurslaag, die wij toch de 'eerste' noemen, namelijk het lokaal bestuur. Tussen de lidstaten bestaan aanzienlijke verschillen in de positie van het lokale bestuursniveau, maar toch wordt wel gesproken van een viertal groepen, of bestuurlijke 'families' in Europa - de Latijnse, de Duitse, de Angelsaksische en de Scandinavische, plus enige tussen-types zoals Nederland. Het lijkt mij persoonlijk beter om de vijftien nationale tradities en eigenaardigheden maar als uitgangspunt te nemen. De verschillen tussen de lidstaten zijn namelijk aanzienlijk. Frankrijk kent meer dan 36.000 gemeenten, waarvan er ruim duizend minder dan vijftig inwoners hebben, met een direct gekozen burgemeester, die vaak meerdere openbare ambten bekleedt - een systeem, dat centralisatie en fragmentatie combineert. Nederland daarentegen heeft thans ruim 500 gemeenten, die op grond van een zelfbedachte minimumnorm van 15.000 inwoners steeds verder worden samengevoegd, en die worden bestuurd door een direct gekozen raad plus een politiek benoemde burgemeester, binnen een stelsel van decentralisatie als norm - zij het niet altijd als realiteit. Bij de verschillen tussen de lidstaten is het wel zo, dat binnen de lidstaten de positie van het lokale bestuur meer uniform geregeld is dan die van het tussenbestuur.

De betekenis van het lokale niveau, in alle lidstaten, is groot en tweeerlei (20). Het is het bestuursniveau, dat het meest direct in aanraking komt met de maatschappelijke problemen van alledag, met 'de samenleving', en het is het niveau, waarop het overheidsbeleid, waar het ook vandaan komt, moet worden uitgevoerd en waargemaakt in direct contact met de burger - op de plaats waar hij woont, werkt en leeft. Het lokale bestuur is daarom voor het bestuursstelsel als geheel onmisbaar als informatiebron over de maatschappelijke problemen, waarvoor het 
overheidsbeleid een oplossing zal moeten zoeken, en over de vraag, in hoeverre bestaand beleid ook "werkt". Als 'the proof of the pudding is in the eating' (ook al is een 'pudding' dan geen lagentaart, maar een specifiek Engelse gebaksoort, die ik niet goed ken en mij ook niet lekker lijkt), dan gebeurt dat op het lokale niveau - dáar moet blijken, wat er in de realiteit met het overheidsbeleid gebeurt. Voor de burger is de gemeentelijke overheid het ware, dagelijkse gezicht van de overheid. In de media en het nationale parlement mogen felle discussies gevoerd worden over milieu, ruimtelijke ordening, veiligheid of gezondheidszorg, waar de burger tegenaan loopt, zijn de kosten en de wachttijd van een paspoort, een vergunning om het huis te verbouwen, de onmogelijkheid om te parkeren, of de wegzakkende stoeptegels vanwege het achterstallige wegenonderhoud. De nationale politiek is de democratie van de televisie, de gemeente-politiek en het gemeentebestuur is de democratie van thuis, de plaats waar de burgers leven, wonen en werken. Overheidsbeleid, dat op Europees, nationaal, of provinciaal niveau wordt gemaakt, moet uiteindelijk ergens bij mensen in hun directe leef-en woonomgeving worden vertaald - want als dat niet gebeurt, geldt voor de democratie hetzelfde als voor de bekende geniale universele groentesnijder: 'it works on television but not at home'. Dit verklaart de relatief grote politieke belangstelling van burgers voor lokale politiek - de opkomst bij lokale verkiezingen is, niet alleen in Nederland maar ook elders in Europa, relatief hoog. De betrokkenheid van burgers bij hun lokale omgeving is duidelijk aanwezig, maar tegelijkertijd is die betrokkenheid altijd gekoppeld aan andere "hogere" loyaliteiten. Iedere burger, hoezeer ook gehecht aan de lokale gemeenschap - ook de kiezer van de Partij Gemeentebelangen - zal altijd erkennen en accepteren, dat de lokale gemeenschap onderdeel vormt van een groter geheel - een regio, een nationale staat - en zal dus bereid zijn om de belangen van dat grotere geheel te laten meewegen of zelfs het overwicht te gunnen. In die zin is lokale loyaliteit altijd gedeelde loyaliteit - gedeeld met andere bestuurlijke niveaus.

Tegelijkertijd betekent dit ook, wanneer er een grote en aanhoudende kloof is tussen de "hogere', regionale, nationale of Europese politieke discussies enerzijds, en anderzijds de gemeentelijke bestuurlijke reali- 
teit voor de burgers, dat er grote kans is op vervreemding, apathie en afkeer van burgers ten opzichte van het gehele politieke en bestuurlijke bestel. Hoe het op lokaal niveau toegaat, politiek en bestuurlijk, is dus van veel meer dan plaatselijk belang. Het raakt een kernvraag, namelijk in hoeverre het politiek-bestuurlijke stelsel als geheel, van Europees tot gemeentelijk niveau, voeling heeft met de samenleving, en in staat is op een voor de burger acceptabele en effectieve wijze problemen door middel van beleid op te lossen.

$\mathrm{Nu}$ wij de vier lagen van onze lagentaart onder ogen hebben gehad, wordt de volgende vraag, waarvoor wij door het ovenvenster moeten kijken: welke betekenis heeft de komst van de vierde, Europese laag gehad voor de onderliggende lagen, en voor het geheel? Wat waren de lusten en de lasten van de Europese bestuurslaag, en welke processen zijn erdoor in werking getreden? Wij beantwoorden deze vraag op twee manieren: verticaal en horizontaal. Verticaal: tussen de bestuurslagen. Horizontaal: op eenzelfde bestuursniveau.

Eerst dus verticaal. Wanneer er op bestaande lagen een nieuwe laag wordt toegevoegd, dan zullen, in natuurkundige termen, de volgende verschijnselen zich voordoen: druk, doorwerking, weerstand, wrijving en verschuiving. Laten wij eens proberen aan deze verschijnselen een politiek-bestuurlijke vertaling te geven.

Druk: in hoeverre betekent de Europese bestuurslaag een druk, een beperking van mogelijkheden, of een extra last (21) voor de andere bestuurslagen? De omvang en de produktiviteit van cle EU-instellingen kunnen het probleem niet zijn. De Commissie, de Raden en het Europees Parlement hebben een omvang en een 'kostenplaatje', die zonder meer slank te noemen zijn, in vergelijking met nationale, provinciale en gemeentelijke overheden in de lidstaten. Het Europees Parlement lijkt misschien qua omvang 'volslank', maar kan qua kosten en voorzieningen de vergelijking met nationale parlementen goed doorstaan.

Wat wel als een druk kan worden gezien, is om te beginnen de werkwijze bij de totstandkoming van EU-regelgeving. Deze is niet altijd efficiènt: de consensuscultuur in Brussel impliceert talloze overleg- 
rondes tussen de besluitvormende instellingen onderling, plus de verplichte en ook niet-verplichte adviesinstanties. Met name de veelgekozen vorm van richtlijnen, die de lidstaten opdragen om hun eigen wetgeving te veranderen, is qua produktiekosten nogal inefficiënt. Eerst wordt op EU-niveau met een grote mate van detaillering een richtlijn geformuleerd, en vervolgens moet iedere lidstaat in de eigen wetgeving een aanpassing, geheel in eigen stijl, totstandbrengen. Een EU-verordening daarentegen, die met rechtstreekse werking voor alle vijftien lidstaten een probleem oplost, is een hoogst efficiënte vorm van regelgeving, die de lidstaten een hoop productiekosten uitspaart.

In het algemeen kunnen wij vervolgens stellen, dat het toevoegen van een nieuwe bestuurslaag gemakkelijk leidt tot groeiende complexiteit en ondoorzichtigheid. Een extra bestuurslaag is werkt belastend: de kans op 'dubbel werk' door verschillende lagen en op het verloren gaan van informatie tussen de lagen wordt groter. Om deze risico's te verkleinen is extra aandacht nodig voor stroomlijning en efficiency, zodat iedere bestuurslaag bij uitstek zijn eigen toegevoegde waarde levert aan het beleidsproces.

Zeker zo belangrijk, als verticaal effect, is vervolgens: de druk, die van EU-regelgeving uitgaat op de andere bestuurslagen door de uitvoeringsverplichting.

De regering van de lidstaten hebben in de afgelopen vijftig jaar weerstand geboden tegen de nieuwe Europese bestuurslaag door zich bij de besluitvorming in Brussel een doorslaggevende plaats te veroveren misschien een goed voorbeeld van 'voorwaartse verdediging".

Er zit njettemin een onvermijdelijke consequentie aan de EU-besluitvorming: wanneer de afspraken zijin gemaakt, moeten de regeringen die thuis uitvoeren. Zij zijn dan niet meer subject, maar object van regelgeving. Nationale overheden worden in feite in een positie van tussenbestuur gezet, vergelijkbaar met de positie van provincies en gemeenten. Niet toevallig heeft recentelijk minister Brinkhorst gesteld, dat in de Europese Unie het Thorbeckiaanse onderscheid tussen autonomie en medebewind zou moeten worden ingevoerd als 'grondwettelijk beginsel': de lidstaten hebben enerzijds cen sfeer van autonome bevoegdheid, maar anderzijds zijn zij vaak eenvoudigweg ver- 
plicht hun medewerking te verlenen aan EU-beleid en - regelgeving. lets sterker geformuleerd, zou men kunnen zeggen, dat de lidstaat steeds meer gereduceerd wordt tot een briefhoofd, "letterhead government". Het briefhoofd wan de wetgeving is nationaal ('wij, Beatrix etc. etc., "La République française, 'het Koninkrijk België' etc.), maar de inhoud van beleid en regelgeving is Europees - made in Europe - en steeds meer gelijk.

Het is begrijpelijk, dat een nationale overheid moeite heeft met deze nieuwe rol en daar niet al te openlijk voor uitkont. Treffend is in dit verband de aanhoudende weigering van de Nederlandse regering om bij wetsvoorstellen aan de Kamer, die voortvloeien uit EU-richtlijnen, in de titel van het wetsvoorstel dit te vermelden. Men stopt het liever weg, en speelt tegenover het parlement het toneelstukje van de nationale soevereiniteit.

Deze positie als tussenbestuur brengt de nationale overheid dichterbif de provincie - en dat veroorzaakt wrijving, of anders gezegd, improductieve concurrentie, die echter tot grote hitte kan leiden. Strikt logisch gezien, kan ook de provincie zich opwerpen als doorgever en uitvoerder van EU-regelgeving - in lidstaten met een federale grondwet is dit op vele beleidsterrreinen zelfs regel. In Nederland is dat echter niet geregeld, en wij zien toch wel provinciale of zelfs gemeentelijke initiatieven op EU-terrein. Provincies en gemeenten zien zich, meer nog dan het rijk, door de komst van de EU-bestuurslaag nog verder tot object van regelgeving worden en steeds minder subject - en proberen daar iets aan te doen.

$\mathrm{Nu}$ zou men kunnen verwachten, dat deze concurrentie en wrijving snel in het voordeel van de nationale overheid zal worden beslecht, gegeven de relatief zwakke positie van provincies en gemeenten ten opzichte van het rijk.

Toch is dat niet helemaal het geval, en wel omdat de vierde, Europese bestuurslaag - en dan met name de Europese Commissie - nadrukkelijk samenwerking zoekt met de tweede en de eerste bestuurslaag. Het Conité van de Regio's, ingesteld bij het verdrag van Maastricht, geeft aan regionale en lokale overheden zelfs formele toegang tot de EUbesluitvorming. Op een aantal belangrijke beleidsterreinen (o.a. het 
structuurbeleid) is het Comite een verplichte adviesinstantie, en zijn de lidstaten in het contact met de Europese Commissie genoodzaakt on het subnationale bestuur in Brussel te laten meespreken. Voor sommige lidstaten - Groot-Brittannië, maar ook Nederland, heeft dat nieuwe kansen en taken voor het tussenbestuur opgeleverd. Om Europa dichter bij de burger te brengen, maar ook om de overheersende rol van de nationale overheden in de Brusselse besluitvorming een beetje te compenseren, worden vanuit de vierde bestuurslaag nieuwe mogelijkheden geboden voor het tussenbestuur en de gemeenten, die zich hiernee soms vrij onverwacht - in Europa zien opgenomen en ingeschakeld.

Speciale aandacht van de Europese Commissie, Parlement en Comité van de Regio's, krijgen daarbij bovendien de lagere overheden in grensregio's - bij uitstek de plaats, waar de samenwerking en eenwording over de landsgrenzen heen gestalte kan krijgen op een zeer praktisch, voor de burgers zichtbaar niveau.

De verticale doorwerking van de vierde bestuurslaag op de andere bestuurslagen moeten wij, vervolgens, zien als een tweerichtingverkeer.

Van boven naar beneden zijn er de 'beleidsprodukten' van de EU, waarmee de andere bestuurslagen moeten werken, d.w.z. regelgeving en subsidies. Van beneden naar boven is er de belangenbehartiging en de inbreng in het EU-beleid vanuit de eerste, tweede en derde bestuurslaag.

EU-regelgeving is na veertig jaar niet alleen zeer omvangrijk geworden, maar beweegt zich ook op steeds meer terreinen. Wanneer wij ook beleidsafspraken en verdragen in de zgn. tweede en derde pijler (buitenlandse zaken en defensie, resp. politie justitie en binnenlandse zaken) als 'regelgevend beleidsprodukt' opvatten - zij het niet in formeel-juridische zin -, dan bemoeit de EU zich in feite met alle terreinen van overheidsbeleid. Het volledige terrein van het binnenlandse bestuur in de lidstaten is onderwerp geworden van EU-besluitvorming - en deze doorwerking duiden wij aan als de binnenlandisering van Europa.

Toch schort er nog wel het een en ander aan de 'omgang' met Europese regels in het binnenlands bestuur. Trage aanpassing via nationale wetgeving, zwakke voorlichting binnen de overheid en naar de 
burgers, en gebrekkige naleving hebben in het recente verleden tot diverse ongelukken geleid. De zgn. Securitellijst was een goed voorbeeld: een groot aantal regels vanuit het ministerie van Economische Zaken was niet tijdig bij de Europese Commissie gemeld en daardoor in beginsel nietig. Gevolg van een dergelijke situatie: een burger of bedrijf kan de nationale regelgeving via het Europese Hof onderuithalen, en de nationale overheid kan uiteindelijk met Europese sancties (boetes) worden geconfronteerd. Na een aantal van dit soort bedrijfsongevallen - men kan de EU-nitraatregels voor de landbouw er ook toe rekenen - zien wij, dat de rijksoverheid actiever wordt - want het rijk is tegenover Brussel financieel en juridisch aansprakelijk. Zo wordt er nu een expertisecentrum 'Europees recht en decentrale over-heden' opgezet vanuit het ministerie van Binnenlandse Zaken en Koninkrijksrelaties, om de provincies en gemeenten bij te staan op het terrein van de EU-regelgeving.

Het is echter goed om bij allerlei nuttige initiatieven toch te benadrukken, dat er in Nederland éen overheidsinstantie is, die de juridische deugdelijkheid van alle regelgeving in dit land tot haar verantwoordelijkheid heeft, namelijk het Ministerie van Justitie. Toegegeven, het is een veelgeplaagd ministerie, maar het is niet anders. De lagentaart van ons openbaar bestuur is al ingewikkeld genoeg, en de taken moeten daar worden gelegd, waar de verantwoordelijkheden liggen. Het ministerie van Justitie behoort tot onze oudste ministeries en is van oudsher bevolkt met specialisten in het Nederlands recht - maar in de huidige situatie hoort daar ook echt het Europees recht bij.

Met de besteding van Europese subsidies, het tweede beleidsprodukt van de EU, doet zich een soortgelijk probleem voor. De gelden, waarover de EU beschikt, zijn allemaal afkomstig uit de nationale schatkisten en uit de nationaal geheven bellastingen (een deel van de BTW) - Nederland heeft bij de onderhandelingen in 1999 ook grote ophef gemaakt over de contributie aan de EU. Toch worden de gelden, die in de vorm van subsidies uit Brussel komen (dat zijn vooral de structuurfondsen1), nog te vaak gezien als 'andermans geld', d.w.z. dat er minder nauwgezet mee wordt omgesprongen. In Nederland zijn het niet zozeer de provinciale en gemeentelijke overheden, maar vooral de 
rijksoverheid, die bij de besteding van EU-gelden en het toezicht daarop, diverse ernstige steken heeft laten vallen. De Nederlandse Rekenkamer heeft hierover onlangs, en niet voor het eerst, gerapporteerd. Ook in bredere, politieke zin komt een slordig beheer van EU-gelden niet ten goede aan de geloofwaardigheid van een lidstaat, die klaagt over de hoge contributie en over de noodzaak van goed beheer.

De problemen rond het beheer van Europese gelden betekenen evenwel voor de verhouding tussen bestuurslagen een versterking van de centrale overheid, die ten opzichte van de provincies en gemeenten waakzamer wordt. De boodschap wordt weliswaar verpakt in de taal van de bestuursakkoorden, afspraken en convenanten, maar komt toch per saldo neer op centralisatie - Mama 'spreekt met Jantje af, dat hij zij bordje leegeet'.

Dan is er het opwaartse verkeer tussen de bestuurslagen 'van beneden naar boven', in het bijzonder de belangenbehartiging vamuit de eerste, tweede en derde naar de vierde bestuurslaag. Wij zagen al, dat de nationale overheden in de EU-besluitvorming zelf een doorslaggevende rol spelen - betere belangenbehartiging van de derde bestuurslaag bij de vierde is nauwelijks denkbaar. Maar hoe zit het met de kanalennaar-Brussel van de eerste en de tweede bestuurslaag?

Over de belangenbehartiging in de EU, het 'lobbyen', bestaan veel misverstanden en fabeltjes. Het Brusselse circuit zo zou ondoorzichtig zijn, dat je niet zonder een specialist kunt, die de weg weet - net alsof het Haagse circuit niet ondoorzichtig is - en een goede lobbyist zou wonderen voor u kunnen doen. Het Europa, dat rommelt, ritselt en 'netwerkt', en waar met een goede list of misschien ook een beetje bedrog, van alles te bereiken is (22). Wie zich door deze gedachten laat meeslepen en zijn belangen toevertrouwt aan een lobbyist, die een goede indruk maakt of die $u$ informeel wordt aanbevolen, kan van een koude kermis thuiskomen.

Er zijn verschillende uitkomsten mogelijk. Ofwel: u krijgt uit de EUsubsidiepot gewoon datgene waarop u recht hebt, maar dit wordt door de lobbyist voorgespiegeld als een zeer bijzonder resultaat, waarvoor u dankbaar moet zijn en u zich aanhankelijk en afhankelijk moet betonen. Ofwel: $\mathrm{u}$ krijgt minder dan waar u recht op hebt, maar dat hebt $\mathrm{u}$ 
niet in de gaten. Ofwel: u krijgt iets, waarop u geen recht hebt, maar wat door uw lobbyist voor u wordt 'geregeld" - dat wil zeggen buiten de regels om of in strijd met de regels verkregen. In dat geval bent u misschien de lobbyist dankbaar, maar u bent vooral afhankelijk, en moreel en juridisch kwetsbaar. Ofwel, laatste mogelijkheid: uw lobbyist gaat er met uw geld vandoor, en $u$ kunt hem of haar alleen nog via de rechter bereiken. Het zijn allemaal dingen die echt gebeuren, en die u te denken moeten geven over lobbyisten - vooral lobbyisten, die een levensbelang hebben bij ondoorzichtigheid.

Dat betekent niet, dat belangenbehartiging noott deugt. Integendeel, in een democratie is belangenbehartiging niet alleen geoorloofd, maar ook belangrijk en nuttig. Goede belangenbehartiging - ik gebruik liever niet de term lobbyen, die is in de jaren ' 20 in de Verenigde Staten terecht in diskrediet geraakt - betekent echter iets heel anders dan 'ritselen" en 'regelen'. Het betekent - en ik zeg dit ook een beetje als vakbondsman -: actief en oplettend zijn, jezelf en degene voor wie je werkt, informeren, niet denken in termen van gunsten maar in termen van rechten en plichten, die openlijk verantwoord moeten worden, en vooral meedoen, participeren, waar dat kan, mag en moet, de mogelijkheden benutten. Goede, dat wil zeggen verantwoorde en effectieve, belangenbehartiging betekent dus vooral: vergaderen, stukken lezen, meedoen in allerlei commissies en werkgroepen - vaak saai, maar heel belangrijk werk. Dit werk is niet gebaat bij de misplaatste glamour van de 'wonderlobbyist'.

Dat geldt dus ook voor de belangenbehartiging van de eerste en tweede bestuurslaag in Brussel (23). Hoe kan die dan het beste worden vormgegeven? In principe zijn er twee mogelijkheden: rechtstreekse belangenbehartiging in Brussel, en gebruikmaken van andere bestuurslagen. Bij dat laatste kunt u denken aan ministeries - van Landbouw, Economische Zaken, Binnenlandse Zaken en Grote Stedenbeleid-, die in de Europese besluityorming meedraaien en het tot hun taak kunnen rekenen om ook de belangen van provincies of gemeenten naar voren te brengen.

Dat gebeurt in de praktijk ook. Het heeft als voordeel, dat de besluitvorming in Brussel niet ingewikkelder wordt dan zij al is, en ook, dat 
men zich concentreert op de Nederlandse speler, die in Brussel sowieso de sterkste stem heef, namelijk de rijksoverheid. Toch zijn er ook nadelen: de rijksoverheid denkt en handelt nationaal en het is dus van belang, dat provincies of gemeenten zich nadrukkelijk laten thoren en alert blijven op wat het rijk met hun wensen in Brussel doet. Bovendien doen zich over de landsgrenzen heen soms mogelijkheden tot samenwerking voor, op het niveau van tussenbestuur of lokal bestuur, die het rijk gemakkelijk over het hoofd ziet - bijvoorbeeld gezanenlijk optreden van grote steden, mijnbouwgebieden of visserijregio's in Brussel.

Het is dan ook zeer begrijpelijk, dat sinds het midden van de jaren ' 80 - de Europese Akte, de campagne Europa-'92 - steeds meer gemeenten en provincies een direkte toegang hebben gezocht naar de EU-besluitvorming. De grote steden, in Nederland vooral Rotterdam, liepen daarbij voorop.

Sinds het verdrag van Maastricht hebben de decentrale overheden bovendien een formeel 'eigen' kanaal gekregen - het Comité van de Regio's. Verder eist het subsidiariteitsbeginsel uit datzelfde verdrag, dat ook de decentralle overheden in alle lidstaten meekijken en zo mogelijk meedoen aan het beleidsproces, niet alleen de uitvoering maar ook de besluitvorming. Ook dat is een reden voor provincies en gemeenten voor directe aanwezigheid en deelname. Voor Nederland heeft dit uiteindelijk geleid tot het Huis van de provincies, dat vorig jaar is geopend en waar de twaalf provincies plus enige grote steden een 'antenne' hebben gevestigd. Daarnaast zijn afzonderlijke grote gemeenten en de Vereniging van Nederlandse Gemeenten in Brussel aanwezig om hun belangen te behartigen hetzij via het Comité van de Regio's, hetzij langs andere wegen. In feite worden de directe en de indirecte belangenbehartiging gecombineerd, en wordt daarnaast ook aan "vrije belangenbehartiging" gedaan, dat wil zeggen niet via een typisch lokaal of provinciaal toegangskanaal in formele zin, maar via contacten met andere EU-instellingen (Commissie, Parlement, advieslichamen etc.).

Voor het succes van de decentrale belangenbehartiging mag men zich overigens afvragen, of het zoveel zin heeft dat iedereen iedereen "voór 
probeert te zijn" door individueel op pad te gaan in Brussel. Misschien geldt het spreekwoord 'hoe meer zielen, hoe meet vreugd', maar waarschijnlijk ook 'hoe meer geluiden, deste zwakker de stem", of 'hoe meer concurrerende belangenbehartigers, deste minder uiteindelijk resultaat'. Dit probleem geldt trouwens niet alleen voor Nederland, maar voor alle lidstaten: in Brussel is het complete bestuur, met alle bestuursiagen, van alle lidstaten aanwezig - via de Permanente Vertegenwoordigingen, het Comité van de Regio's, en hun vele tientallen gezamenlijke of individuele kantoren.

Dat brengt ons meteen op het tweede antwoord op de vraag naar de effecten van de Europese bestuurslaag, namelijk de horizontale effecten. Omdat als gevolg van de Europese integratie het gehele bestuur van de lidstaten betrokken is geraakt bij de EU-besluitvorming en omdat de grenzen tussen de lidstaten ook in feitelijk maatschappelijke en economische zin zijn vervaagd - zeker sinds de vermindering c.q. afschaffing van de grenscontroles - zijn op alle bestuurlijke niveaus de contacten, de mogelijkheden tot samenwerking en tot concurrentie, enorm gegroeid. Er is niet alleen een Europese economische markt ontstaan, maar ook een 'Europese bestuurlijke markt' op ieder niveau. Op lhet nationale niveau betekent dit allereerst, dat er binnen de rijksoverheid tussen de ministeries bewust moet worden gecoördineerd (24). Om zo effectief mogelijk te opereren, is het voor een lidstaat, en zeker voor een betrekkelijk klein land als Nederland, van groot belang, dat er 'met éen mond wordt gesproken' of tenminste, dat er geen tegenstrijdige standpunten worden uitgedragen. Deze coördinatie vindt binnenlands (in Den Haag) plaats, maar de P.V. speelt daarbij een essentièle rol.

Vervolgens betekent de EU-besluitvorming voor de nationale overheid, dat er voortdurend met andere lidstaten moet worden samengewerkt en/of geconcurreerd binnen het geheel van de procedures en spelregels. Dat vereist een strategie, waarin het nationale belang vooropstaat - daarvoor staat de nationale overheid immers -, maar waarin toch op langere termijn de Europese samenhang als kader moet dienen. Nederland koos tot het begin van de jaren negentig een strategie van 
steun aan de supranationale instellingen (Commissie, Parlement), zonder overigens het nationale belang in de Raden te verwaarlozen. Het was in feite niet nodig om het eigen, Nederlands belang nadrukkelijk naar voren te brengen, omdat het EU-beleid daar sowieso wel voor zorgde - met name het landbouwbeleid. De hervorming van het Gemeenschappelijk Landbouwbeleid, de toetreding van steeds meer lidstaten tot de EU, en de schok van Maastricht - ook wel bekend als Zwarte Maandag - hebben ervoor gezorgd, dat Nederland nadrukkelijk het nationale belang is gaan bepleiten. Daarbij zijn echter nog een aantal belangrijke strategische vragen onbeantwoord gebleven (25). Moet Nederland het vooral hebben van 'netwerken' met de andere lidstaten, van 'benchmarking', 'peer pressure' en 'best practice', zoals staatssecretaris Benschop lijkt te prediken, of moeten wij alles op alles zetten om binnen de instellingen en spelregels een zo sterk mogelijke positie te krijgen? Bijvoorbeeld, door ons stemmengewicht in de Raad te vergroten, zoals premier Kok gedaan lijkt te hebben in Nice. Overigens is het resultaat helemaal geen vergroting, maar een verkleining ten opzichte van de grote lidstaten, zij het dan een iets minder grote verkleining dan België heeft gekregen - volgt u mij nog? In de Verenigde Staten doet men enige weken over het tellen van stemmen, in Europa enige jaren over het wegen ervan - zo heeft iedereen zijn zorgen, maar dit terzijde ...

Het lijkt voor Nederland, als middelgroot land in een groeiende EU, van belang om twee lijnen te volgen. Enerzijds de lijn van goede betrekkingen met de grote lidstaten - met Duitsland, maar ook met Frankrijk, Groot-Brittannië, Italië en Spanje -, en anderzijds van nadrukkelijke inzet voor multilateralisme, dat wil zeggen versterking van de supranationale instellingen en spelregels. Dit laatste betekent ook een correcte, zeg maar voorbeeldige, naleving van de regels. Dat berust niet op zweverig of dogmatisch Euro-idealisme, maar op welbegrepen eigenbelang. Een klein land heeft morele middelen en goed gedrag nodig om zich te kunnen handhaven en zijn invloed te maximaliseren. In die zin is de aloude koopman-dominee-traditie voor Nederland zeer passend. Het gaat daarbij niet alleen, of niet zozeer, om succes op de korte termijn, maar vooral om de betrouwbaarheid van 
Nederland als partner en medespeler binnen de EU. Overigens sluit een dergelijke strategie zeker niet uit, dat Nederland aansluiting zoekt bij coalities in de Europese besluitvorming, liefst flexibele en wisselende coalities - de tijd is voorgoed voorbij, dat Nederland in zijn eentie binnen de EU tot resultaten kon komen. Nederlandse solo-acties of 'alles-of-niets'-opstellingen leiden tot niets.

Een horizontaal effect van de Europese samenwerking doet zich ook voor op de tweede en de eerste bestuurslaag. Allereerst is er de noodzaak van binnenlandse samenwerking. Het kennen en naleven van de regelgeving, participeren in en profiteren van EU-mogelijkheden en behartigen van belangen in Brussel is voor iedere afzonderlijke gemeente vaak onmogelijk en in feite ook niet wenselijk. Van de ruim 500 Nederlandse gemeenten mogen de vier grote steden dan hun eigen weg in Brussel volgen - gesteund vanuit de derde bestuurslaag, namelijk de minister voor Grote Stedenbeleid -, voor verreweg de meeste is het alleen zinvol om via de Vereniging van Nederlandse Gemeenten te werken. Je moet er niet aan denken, dat alle tienduizenden gemeenten binnen de $\mathrm{EU}$ zich in Brussel zouden laten zien. Verscheidenheid is mooi, maar teveel ervan is volledig contraproduktief.

Dat geldt in mindere mate ook voor de provincies. Het wordt steeds duidelijker, dat voor de contacten met de Europese Commissie, het Comité van de Regio's, en voor het meedraaien in de regionale subsidieprogramma's een groepering van Nederlandse provincies nodig is. Steeds nauwere samenwerking in de vorm van landsdelen - Nederland-Noord, -Oost, -Zuid, en -West, plus een eventuele Randstadregio - wordt een steeds duidelijker perspectief. Dat kan voor het tussenbestuur in Nederland belangrijke consequenties hebben - de twaalf provincies zouden op den duur kunnen opgaan in vier of vijf landsdelen.

Voor de provinciale en gemeentelijke contacten over de landsgrens heen heeft de EU ook belangrijke consequenties. In de besluitvorming binnen het Comité van de Regio's moeten coalitiepartners worden gevonden, en dat kan alleen wanneer men over en weer enig begrip en inzicht heeft in de wederzijdse achtergronden en belangen. Nederlandse provincies en gemeenten, vertegenwoordigd in de Nederlandse 
delegatie, worden daardoor gedwongen hun blikveld te verruimen. Daarbij hebben de provincies de handicap, dat het niet eenvoudig is de juiste gesprekspartner in de andere lidstaten te vinden - de Belgische gewesten of de Belgische provincies? de Franse régions of de départements? De Duitse Länder of de Regierungsbezirke? In de praktijk valt dit probleem mee en krijgt de Nederlandse provincie in feite de kans om 'mee te liften' met grotere broers in andere lidstaten.

Deze contacten zijn van aanzienlijk belang voor de Nederlandse decentrale overheden. Bij de EU-structuurfondsen moet Nederland alle zeilen bijzetten om zijn aandeel te handhaven. In de toekomst is een daling vrijwel onontkoombaar. Wanneer wij een rol in het structuurbeleid willen blijwen spelen, en daar direct of indirect baat bij willen houden, dan zullen creatieve en intensieve contacten met decentrale overheden in andere lidstaten en toetredingslanden steeds belangrijker worden.

De noodzaak tot grensoverschrijdende samenwerking op de eerste en tweede bestuurslaag geldt nog sterker voor de subsidieprogramma's van de Europese Commissie (de zgn. communautaire initiatieven) - zij is daar in feite een 'must'. Een speciale plaats daarin hebben de Euregio's, de bestuurlijke samenwerkingsverbanden tussen lokale en regionale overheden aan de grenzen van de lidstaten. Zij genieten de speciale steun van de Europese Commissie, om op de werkvloer van het openbaar bestuur, de dagelijkse wereld van wonen, leven en werken van de burgers, verbindingen te leggen over de nationale grenzen heen en zo de nationale staten te overwinnen door ze aan elkaar te verbinden. Juist in grensgebieden doet zich voor, wat Jan Romein de 'wet van de remmende voorsprong' noemde, en wat elders is aangeduid als "de eersten zullen de laatste zijn, en de laatste eersten". Door het vervagen van nationale grenzen kan grensoverschrijdende samenwerking tussen voormalige achterblijvende grensgebieden een grote sprong voorwaarts betekenen ten opzichte van voormalige koplopers in de lidstaten.

Dat brengt ons, horizontaal kijkend, op de bodem van onze lagentaart, namelijk de samenleving en de economie. De komst van de vierde be- 
stuurslaag heeft daar in de afgelopen decennia grote gevolgen gehad, omdat zij economische groei, mobiliteit, schaalvergroting en Europeanisering heeft mogelijk gemaakt en gestimuleerd. Het wegvallen van de grenscontroles en straks het gebruiken van een gezamenlijke valuta, de Euro, zijn daarvan de meest zichtbare uitingen. De invoering van de euro zal vrijwel zeker een stroomversnelling teweegbrengen in dit maatschappelijk Europeaniseringsproces. De dynamiek doet zich het duidelijkst voor in grensregio's, maar het gaat om een veel breder verschijnsel. Arbeidsmigratie binnen Europa - vooral aan de onderkant, maar ook aan de top van de arbeidsmarkt - bedrijfsinvesteringen, fusies en overnames, verkeers- en ruimtelijke ordeningsproblemen het vollopende en dichtslibbende noordwesten van Europa - recreatieve mobiliteit - een tentoonstelling in Londen, een concert in Milaan, maar ook het overwinteren in Spanje - het zijn processen die nationale grenzen in politiek en bestuurlijk opzicht steeds minder effectief en relevant maken. Het is de vraag, of deze processen 'op de bodem' het politiek-bestuurlijke bouwwerk onderuit zullen halen of dat wij erin zullen slagen het zodanig aan te passen, dat het overeind blijft.

$\mathrm{Nu}$ wij onze politiek-bestuurlijke lagentaart verticaal en horizontaal hebben bekeken door het ovenvenster, kunnen wij ingaan op een paar algemene vragen.

Is er in dit geheel nu sprake van bestuurlijke versmelting, vervlechting of integratie?

Wanneer wij integratie zien als een groeiende binding in een groter geheel zonder identiteitsverlies van de delen, dan heeft de Europese samenwerking de identiteit van de afzonderlijke deelnemers, de taartpunten uit onze Europese spekkoek, in geen geval laten verdwijnen. Ook bij de oudste deelnemers, zoals Nederland, is er geen sprake van bestuurlijk identiteitsverlies - de verschillende bestuursstructuren in de lidstaten, hun eigen bestuursculturen, hun rechtsstelsels - zijn niet aangetast. Je kunt je nog steeds Nederlander of Belg of Duitser voelen binnen de EU, ook in politiek en bestuurlijk opzicht.

De binding in een groter Europees geheel zit hem niet in de structuren, maar vooral in de beleidsinhoud. Zonder dat de burger dat in de gaten 
heeft, is het beleid, inhoudelijk gezien, in de afgelopen veertig jaar binnen Europa op steeds meer terreinen in dezelfde richting getrokken, geconvergeerd. De opgebouwde regelgeving, het acquis, heeft ervoor gezorgd, en blijft ervoor zorgen, dat de nationale schepen-vanstaat steeds meer dezelfde beleidskoers varen, in konvooi dus.

Daarnaast is die Europese binding ook versterkt, doordat er in de afgelopen decennia een Europese 'policy community' (26) is ontstaan, een 'beleidsgemeenschap', dat wil zeggen een groeiende groep mensen die langdurige ervaring hebben opgebouwd met het maken van beleid in Europees verband. U vindt deze 'bestuurlijke Euro's' bij de EU-instellingen, maar ook bij nationale overheden in de lidstaten, bij allerlei belangengroepen, provincies, gemeenten en Euregios. Hoewel zij niet echt talrijk zijn - wat zijn enkele tienduizenden op een bevolking van honderden miljoenen? - vormen zij onderdeel van de politiek-bestuurlijke elite, en spelen een invloedrijke rol, die alleen maar groter wordt, naarmate de EU zich met meer terreinen bezighoudt.

Bestuurlijke vervlechting is er ook, in de zin, dat er tussen de oudere bestuurslagen en de nieuwe vierde bestuurslaag organisatorische knooppunten en verbindingen zijn aangebracht, en ook dat er tussen de 'taartpunten', de lidstaten, ook op de eerste en tweede bestuurslaag, knooppunten en koppelingen zijn ontwikkeld.

Dat brengt ons echter wel op de vraag: hoe diep is de EU doorgedrongen in de binnenlandse bestuursapparaten van de lidstaten? Het antwoord daarop kan ik u nog niet helemaal geven - het is, zoals dat heet, onderwerp van aanhoudend onderzoek, zoniet aanhoudende zorg -, maar ik durf wel enige indrukken te geven. Europese en grensoverschrijdende samenwerking is overal in het binnenlands bestuur aanwijsbaar, maar is niet sterk verankerd in de organisatie en de cultuur van het binnenlands bestuur. Er bestaat in het openbaar bestuur méer Europeanisering dan in het parlement, de partijpolitiek, de media en de publieke opinie, maar veel minder dan in de economie en in de samenleving. Bestuur, politiek, samenleving en economie lopen in dit opzicht dus flink uit de pas - en dat kan leiden ofwel tot een toestand waarin de zwakste schakel het tempo van het geheel bepaalt, ofwell tot lelijke struikelpartijen. 
Is er dan misschien, zoals in de literatuur wel wordt beweerd, in Europa nu sprake van 'meerlagenbestuur', van 'multi-level governance" (27)? Wanneer wij deze laatste term breed opvatten, dan kunnen wij zeggen: inderdaad, binnen de EU worden alle bestuurlijke niveau's geraakt door een integratieproces, en laten zich ook allemaal zien en horen - met name in Brussel.

Daar staat tegenover: het is in Europa echt niet zo, dat voor alle, of zelfs alle grote, beleidsproblemen alle bestuurslagen worden ingeschakeld. Wanneer wij de onderlinge verhouding van de verschillende niveaus bezien - hun relatieve invloed, hun hulpbronnen - dan lijkt het er toch op, dat het nationale niveau politick en bestuurlijk domineert.

Ik wil dan ook maar liever vasthouden aan het beeld van de lagentaart, waar bovenop de nationale taartpunten een Europese bovenlaag is aangebracht. Deze vierde, gezamenlijke laag heeft een grote betekenis gehad en heeft die nog steeds - zeker in de richting van economie en samenleving -, maar in het bestuursstelsel heeft zij vooralsnog geleid tot een versterking van de derde, nationale laag, zowel naar Europa - de steeds meer inter-goevernementele besluitworming in Brussel - als naar de burger en, in iets mindere mate, naar de decentrale overheden. Men zou kunnen zeggen: de vierde, bovenlaag in de taart is verdund en verzwakt, de derde is opgezwollen.

De nationale staat is de relatieve winnaar van de Europese integratie geworden en heeft Europa voor de burger onzichtbaar gemaakt. In de literatuur is de EU daarom wel aangeduid als de "rescue of the nationstate", en is ook wel gezegd 'the nation state strikes back'.

Die overwinning heeft echter wel zijn prijs, een prijs zo hoog, dat wij misschien beter van een Pymhus-overwinning kunnen spreken. Er zijn namelijk in dit verhaal twee verliezers, namelijk de geloofwaardigheid van het overheidsbeleid en de democratie.

In het overheidsbeleid speelt de nationale staat verstoppertje, of nog erger, doet hij aan merkvervalsing. Het beleid wordt gemaakt in EUverband, maar wordt aan de burger gepresenteerd als nationaal beleid: het merkje 'made in Europe' is overgeplakt met een merkje 'made in Holland". Het feitelijk verlies aan soevereiniteit, d.w.z. oppermacht, wordt aan het oog onttrokken, terwijl iedere goede toeschouwer kan 
zien, dat dit nationale toneelstukje niet overeenstemt met de werkelijkheid.

De tweede verliezer is de democratie, on te beginnen op het nationale niveau. Het nationale parlement heeft steeds minder reële invloed op het beleid - dat immers steeds meer in EU-verband wordt gemaakt -, zonder dat dit wordt gecompenseerd door een toenemende invloed van de volksvertegenwoordiging op EU-niveau. De volksvertegenwoordiging op lokaal en provinciaal niveau is gewend om haar invloed te delen met 'hogere' niveaus, dus daar is de democratische schade gelukkig minder groot. Ik kom zo dadelijk met een voorstel om aan dit probleem iets te doen, maar eerst kijk ik nog even met u verder naar onze bijna vijftig jaar oude lagentaart.

Die taart is en wordt namelijk nogal eens uit de oven gehaald. Daarvoor kunnen twee redenen zijn - om te kijken hoe het ermee staat, en om nieuwe taartpunten toe te voegen.

In het eerste geval hebben wij het over een periodieke test, een 'grote beurt', voor de EU. Gaat alles naar wens, lopen de zaken zoals verwacht, zijn er misschien acute problemen die verholpen moeten worden, of moet de hele opzet worden veranderd? Dit zijn de vragen, die aan de orde komen bij de zogenaamde IGC's, Intergoevernementele Conferenties - de naam is alweer veelzeggend over de invloed van de nationale regeringen -, die de voortgang en de opzet van de EU moeten bewaken. Deze conferenties worden de laatste jaren steeds vaker gehouden en zijn een bijna permanent verschijnsel aan het worden. De taart wordt voortdurend uit de oven gehaald, en de oveninstellingen - temperatuur, tijd - voortdurend veranderd. Soms lukt het om het integratieproces vlot te trekken en te versnellen - de periode 19861992 was daarvan een goed voorbeeld -, maar veel vaker leiden pogingen tot versnelling en intensivering juist tot een terugslag en een vertraging - de discussies over de politieke finaliteit, federalisme, Europese grondwetten, kopgroepen en 'coopération renforcée' (28) illustreren dit. Het uit de oven halen, en vervolgens hoger zetten van de oven is misschien goedbedoeld, maar kan volkomen averechts werken en de bovenlaag van de talart doen barsten. Het is beter, om 
voorzichtig te werk te gaan, en vooral veel zorg te geven aan de zwakste lagen in de taat - dus de vierde, de tweede en de cerste, en niet de derde. Dus: de oven wat lager zetten, dichtlaten en de tijd zijn werk laten doen. Om een andere beeldspraak te gebruiken: wie een plant will laten groeien, moet hem niet voortdurend uit de grond trekken on te kijken of er al wortelies aan zitten. Een permanente IGC lijkt ons dus geen goed idee.

In het tweede geval hebben wij het over toetredingen tot de EU, nieuwe Landen, die, meestal met een antal tegelijk, hd worden. Momenteel staan wij in dit opzicht voor een geheel nieuw verschijnsel, namelikk zo'n twaalf toetredingslanden - in Midden- en Oost-Europa - die een periode van bestuurlijke en politieke kalslag achter zich hebben. Je zou kumnen zeggen, taatpunten zonder een eigen structuur, lege punten, die met een geheel nieuwe 'Europese' structuur moeten worden ingevuld. Deze toetredingslanden verwachten van het EU-lidmatschap een complete nieuwe binnenlandse staatsinrichting, die voldoet aan de EU-maatstaven. Dat geeft aan de vijfien bestaande lidstaten grote mogelijkheden om hun ervaringen en modellen over te dragen, maar ook een grote verantwoordelijkheid.

Bovendien moet men in Midden- en Oost-Europa op twee andere zaken letten. De verhoudingen en ontwikkelingen in de samenteving en de economic, dat is de voedingsbodem voor het openbaar bestum, moeten passen bij het EU-lidmaatschap - recht en orde, een stabiele en actieve 'civil society' moeten vaak vanaf de grond worden opgebouwd en zijn in elk geval niet vanzelfsprekend. Een tweede zaak is het nationalisme, dat bij de nieuwe post-communistische landen zeer sterk is - misschien begrijpelijk, mar in strijd met de grondgedachte van cle EU, namelijk het overwinnen van nationale tegenstelling door steeds nauwere samenwerking. Toetreding tot de EU betekent afzien van nationalisme en samenwerking met de buren - en op de Balkan zien wij iets anders. Dit alles betekent, dat de voorbereiding van deze twaalf op het EU-lidmaatschap veel moeilijker is, en veel langer gaat duren, dan bij eerdere toetredingen. Wij moeten onszelf en de toetredingslanden daarover geen sprookjes vertellen en illusies voorhouden, maar tegelijkertijd zullen wij ons langdurig en solidair moeten inspan- 
nen om naar het EU-lidmaatschap toe te werken. Tussen de huidige lidstaten en de Midden- en Oost-Europese toetreders is meer openhartigheid én inspanning nodig op het EU-niveau, maar ook op de niveaus van nationaal bestuur, tussenbestuur en lokaal bestuur

Wanneer wij terugkijken naar de Europese lagentaart van de afgelopen vijftig jaar en vooruitkijken naar de toekomst, dan lijkt het van steeds groter belang om in het openbaar bestuur en het overheidsbeleid meervoudig te leren denken en werken: niet in termen van of-of, maar van en-en, niet exclusief maar inclusief. Beleid is steeds minder het exclusieve produkt van éen bestuurslaag, maar steeds meer een co-produktie van meerdere bestuurslagen. Om tot een goed, dat wil zeggen effectief probleemoplossend en democratisch verantwoord, beleid te komen is een maximale voeling van het openbaar bestuur met de samenleving nodig, plus de mogelijkheid om alle bestuurslagen in te schakelen. Dat betekent niet, dat ieder beleid door alle bestuurslagen samen moet worden gemaakt, maar wel, dat er zodanige koppeling tussen bestuurslagen bestaat, dat iedere bestuurslaag zijn specifieke meerwaarde kan bijdragen. Geen enkele bestuurslaag mag ten opzichte van de andere verstikkend en verstoppend werken - en dat lijkt nu bepaald niet het geval.

Dit meervoudige, inclusieve denken geldt ook voor de politieke loyaliteiten in ons werelddeel. U bent niet óf Nederlander óf Europeaan, maar én Europeaan én Nederlander, én Limburger/Hollander én Maastrichtenaar/Amsterdammer.

Dat brengt mij bij een voorstel tot herziening van twee Europese instellingen, namelijk het Comité van de Regio's en het Europees Parlement (29). Het Comité van de Regio's is na 1992 van start gegaan als vertegenwoordiger en toegangskanaal van de decentrale overheden in de EU-besluitvorming, met een aantal substantiële adviesbevoegdheden. Het functioneren ervan laat evenwel te wensen over enerzijds door factoren buiten de macht van het Comite, anderzijds ook door interne ontwikkelingen, en dan met name de politisering binnen het Comité langs partijpolitieke lijnen. 
Gegeven deze situatie, zou het te overwegen zijn, om het Comité, compleet met zijn bevoegdheden en zijn leden, toe te voegen aan het Europees Parlement. Dat zou de bevoegdheden van het Comité niet verzwakken - integendeel, de leder worden ook lid van het Europees Parlement en zien daarmee hun rol versterkt -, het zou de bevoegdheden van het Europees Parlement evenmin verzwakken - het krijgt de bevoegdheden van het Comité erbij - en het zou de toegang van de decentrale overheden tot de EU-besluitvorming versterken.

Voor het Europees Parlement zou de "overkomst" van het Comité van de Regio's goed kunnen aansluiten bij de discussies over een Europese Senaat, waarin de nationale parlementen toegang zouden moeten krijgen tot Europese besluitvorming - iets, wat hard nodig is. Wij komen dan uit bij een Europees Parlement, dat uit drie Kamers bestaat - of in ieder geval drie soorten leden heeft. Een direct gekozen Eerste, Europese Kamer - met leden uit Europese politieke groeperingen, gekozen op basis van Europese politieke discussies en nadrukkelijk toegewijd aan het algemeen-Europese belang *, een Tweede Kamer - met leden, gekozen door de nationale parlementen -, en een Derde Kamer - met leden, gekozen door de regionale en lokale volksvertegenwoordigingen, dat wil zeggen voor Nederland de provinciale Staten en de gemeenteraden.

Met een dergelijke herziening zouden meerdere goede zaken gediend zijn: de transparantie en overzichtelijkheid - het losstaande Comité van de Regio's zou verdwijnen -, de democratie - het volksvertegenwoordigende karakter van het Europees Parlement zou aanzienlijk worden versterkt, en de eis van grotere invloed voor het Europees Parlement, bijvoorbeeld bij de verkiezing van de President van de Commissie, zou aanzienlijk aan kracht winnen -, en de koppeling tussen de bestuurslagen - van het lokale tot en met het Europese niveau. Kortom, dit voorstel wordt beleefd doch dringend in uw aller aandacht aanbevolen.

Achtergrondgedachte bij dit voorstel - en eigenlijk ook bij deze hele voorafgaande beschouwing -, is dat de Europese samenwerking veel meer is dan een kwestie van geld of markt. De versmalling van de EU 
tot een financiële discussie - bekend is de uitspraak van Margaret Thatcher 'I want my money back', en iets minder bekend is de uitspraak van premier Drees bij de ondertekening van de verdragen van

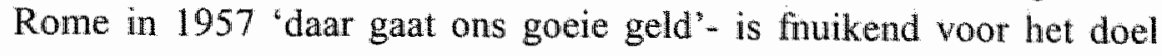
van de Europese samenwerking, nl. een groeiende eenwording van de volkeren van Europa (zie de verdragen van Rome en Maastricht), het oplossen van de grote problemen van onze samenleving, en het realiseren van een aantal waarden.

Jawel, de EU staat in dienst van een aantal waarden. Het zijn: welvaart, vrede, veiligheid, democratie, rechtsstaat, vrijheid, tolerantie, menselijke waardigheid en gelijkwaardigheid en maatschappelijke solidariteit - de 'freedom from fear', zoals de Amerikaanse president Johnson het noemde in zijn 'war on poverty'. Deze waarden zijn niet exclusief Europees, en kunnen dus niet het alleenrecht zijn voor Europeanen. Europa is daarom verplicht om vanuit deze waarden ook open te staan voor wat er in de rest van de wereld gebeurt, en niet alleen met zichzelf bezig te zijn. Uiteindelijk leeft meer dan de helft van de wereldbevolking in het zuiden en oosten van Azië, en is westEuropa niet meer dan een welvarende, enigszins verwende villawijk in de wereld.

Dit gezegd zijnde, vraagt u zich misschien nog af, wat vanuit deze leerstoel - regio-bestuur in internationaal perspectief - aan al deze belangrijke zaken gedaan kan worden. Ik noem u daarom zeer kort mijn voornemens voor wat betreft onderzoek en publikatie.

Dat is, in de eerste plaats, om binnen het binnenlands bestuur in Nederland Europa meer bekend te maken, en om, zonder de EU te idealiseren, te laten zien, hoe de EU werkt en welke meerwaarde het te bieden heeft aan het overheidsbeleid. De EU moet veel meer bekend worden, en moet ook veel gewoner worden - niet een exotisch vakantie-oord voor bestuurders en ambtenaren in Brussel, Straatsburg of Luxemburg, maar een normaal, bruikbaar en waardevol onderdeel van het bestuursstelsel.

Ten tweede, duidelijk maken, wat de andere lidstaten en adspirant-lidstaten in Europa bezielt en beweegt, bestuurlijk, politiek en ook histo- 
risch, cultureel en economisch. Om met de collega's in Europa goed te kunnen samenwerken, moet een Nederlandse 'binnenlandse" bestuursambtenaar enig begrip hebben voor hun achtergrond en hun situatie. Nederlandse ambtenaren zijn nog te vaak naar binnen gericht, ondanks ons zelfbeeld van internationale openheid. Om dat hoognodige begrip te verkrijgen, heb ik in ieder geval een eenvoudig advies: leer de taal, lees de krant uit een ander land, en stop dan niet op de buitenlandpagina maar ga door naar het binnenlandse nieuws. Daar ontdekt $u$, wat er in de samenleving van een ander land speelt. Probeert u zich eens te verplaatsen in het denken en doen in andere lidstaten. $U$ zult $u$ daarvan veel plezier hebben in het Europese werk. Wij kunnen veel leren van anderen, en: wie belangstelling geeft, krijgt dubbel en dwars belangstelling en goodwill terug.

Ten derde, inspelen op de praktische problemen en behoeften, die vanuit het Nederlandse binnenlands bestuur naar voren komen op het terrein van grensoverschrijdend en Europees werk. Dat betekent, naast de zojuistgenoemde twee voornemens, ook: beleidsanalytisch werk (30) op inter-bestuurlijk terrein, analyse van knelpunten, succes- en faalfactoren, evaluatie en planning op een zeer concreet niveau. Deze leerstoel moet niet alleen in de universiteit, maar ook dichtbij het openbaar bestuur zijn waarde bewijzen, vooral voor de eerste, de tweede en de vierde bestuurslaag.

Tenslotte: wij leven hier in Europa in een werelddeel, waarin het overheidsbeleid zich gesteld ziet voor grote problemen en uitdagingen - en het is nodig om die onder ogen te zien. Tegelijkertijd echter is dit een werelddeel, dat in historisch, politiek, sociaal en cultureel opzicht een enorme verscheidenheid, rijkdom en schoonheid kent - een fascinerend werelddeel, waar het een voorrecht is te mogen leven en werken.

Dames en heren, na deze emstige beschouwingen en deze talrijke ovengeheimen is het nu tijd voor enige woorden van dank.

Het College van Bestuur van de Universiteit van Maastricht, in het bijzonder de hier aanwezige voorzitter, wil ik danken voor zijn bereidheid, mij deze leerstoel te laten bekleden. $U$ wist misschien, dat u met 
mij iemand in huis hebt gehaald met een brede belangstelling, iemand die het in het verleden niet kon laten zich met allerlei andere, zeer uiteenlopende onderwerpen en zaken te bemoeien, variërend van de federale stelsels in Canada en India, problemen van bestuurlijke integriteit, het bestuur van de Nederlandse Antillen, het hoger onderwijsbeleid in Nederland of de universitaire c.a.o. Ik dank $u$ voor het in mij gestelde vertrouwen en hoop een nuttige bijdrage te kunnen leveren aan de groei en bloei van de Universiteit van Maastricht.

Bij de Faculteit Rechtsgeleerdheid en de Capaciteitsgroep Metajuridica heb ik al een hartelijke gastvrije ontvangst en collegiale steun mogen ervaren in brede kring. Ik ben daarvoor zeer erkentelijk, en ik wil daarbij in het bijzonder de collega's Amo Korsten en Nico Roos noemen. Ik zie met vreugde uit naar de komende, verdere samenwerking en ik verwacht daar veel van.

Aan de universiteit van Leiden - College van Bestuur, Faculteit Sociale Wetenschappen en Departement Bestuurskunde - wil ik diegenen dankzeggen, die zich actief hebben ingezet voor mijn benoeming.

Het Instituut Clingendael, mijn huidige werkplek, mag daarbij niet onvermeld blijven. Als dagelijkse thuisbasis biedt het mij de gelegenheid om mijn bredere taak - Europa en het binnenlands bestuur - naadloos te laten aansluiten op het werk hier in Maastricht. Ik wil daarbij in het bijzonder de heren van Staden, Rood en Pijpers noemen, en waardeer de anwezigheid van een aantal Clingendaelers bij deze oratie ten zeerste.

Het bestuur van de Raad van Europese Gemeenten en Regio's, dat deze leerstoel heeft ingesteld en meegewerkt aan mijn benoeming, heeft mij al aangeduid als 'onze hoogleraar'. Ik ben u daarvoor zeer erkentelijk en zal u dan ook aanduiden als 'mijn bestuur'. $U$ dwingt mij niet alleen tot een toespitsing en concentratie van mijn onderzoek - iets wat mij zeer welkom is -, u biedt mij ook een unieke gelegenheid tot contact en voeling met de praktische problemen van het grensoverschrijdend en Europees werk vanuit het Nederlandse binnenlands bestuur. Ik hoop die gelegenheid volop te benutten - tot wederzijds profijt. Ik neem mij voor om vanuit deze leerstoel de bestuurskunde te beoefenen zonder overmatige pretentie of modieusheid, maar met 
creativiteit en onafhankelijkheid en vooral met een maximale betrokkenheid bij de problemen van ons openbaar bestuur.

Dames en heren studenten: deze leerstoel is gericht op onderzoek, maar dat betekent niet dat wat hier gebeurt voor u geen betekenis zou hebben, of dat de bekleder van deze leerstoel niet in u geinteresseerd zou zijn. Onderwijs en onderzoek zijn binnen een universiteit onlosmakelijk aan elkaar verbonden - dat onderscheidt de universiteit van een onderzoekslaboratorium of een hogere beroepsopleiding (zonder dat ik daarmee iets diskwalificerends bedoel over deze twee). Aan u, als nieuwe academische generatie, moet het stokje worden overgedragen. Deze leerstoel biedt u geen verplichte cursussen, maar op het eerste gezicht een interessante franje. Een universiteit is echter geen gestroomlijnde studentenverwerkende industrie, maar een instelling waar $\mathrm{u}$ de gelegenheid hebt voor een brede academische vorming, een Bildung. Vanuit dat oogpunt reken ik op uw belangstelling.

Tenslotte, dames en heren: in beginsel zijn persoonlijke gevoelens niet bedoeld voor publieke vertoning - dat is een kwestie van eenvoudige Gallische logica, Noord-Hollandse nuchterheid, en goede smaak. Diegenen, die in persoonlijke zin bij deze gebeurtenis betrokken zijn geweest - en dat zijn er velen - zal ik dus op een gepast tijdstip en op gepaste wijze daarover berichten.

$\mathrm{lk}$ moet echter twee uitzonderingen maken. Allereerst mijn ouders zij behoren weliswaar tot het verleden, maar zoals u weet "in het verleden ligt het heden, in het nu wat worden zal'. Hun vanzelfsprekende inzet voor anderen, hun volharding, hun grote nieuwsgierigheid en ambitie, en hun nietsontziende nuchterheid zijn voor mij een grote bron van inspiratie geweest, en zijn dat nog steeds. Dat zij hier niet kunnen zijn, is erg jammer, maar deste meer verheugt het mij, dat hun generatie in de persoon van mijn schoonmoeder hier wel aanwezig is.

Tenslotte - en dan heb ik het over het verleden, het heden én de toekomst - mijn echtgenote, Henny. Het klinkt obligaat, maar het is toch waar - wat zij voor mij betekent en betekend heeft, laat zich hier niet 
goed in woorden uitdrukken. Dat zij hier vandaag is, met onze kinderen, is voor mij 'ware vreugde'.

Ik heb gezegd. 
(1) Vgl. het sociologische onderscheid tussen "locals" en "cosmopolitans".

(2) In Nederlandse bestuurskunde is vooral door I. Snellen en A. Zuurmond de betekenis van de ICT voor het openbaar bestuur onderzocht. Ook, in het kader van 'postmoderri bestuur', door P. Frissen

(3) Men denke met name aan het werk van $\mathbb{A}$. de Swaan. Elders in het politieke spectrum echter ook: W. Frijhoff, F. Bolkestein, 'Internationalisme', Willem van Oranjelezing-2000, Delft, 2000

(4) Zie woor een overzicht van de protestants-christelijke politieke ideeen $W$. Banning, Hedendagse sociale bewegingen, Amhem, 1964

(5) Zie boven, alsmede G.H. Sabine \& T.L. Thorson, A history of political theory, 4 th edition, Oxford etc., 1975

(6) B.I.S. Hoetjes, "The European tradition of federalism, the protestant dimension', in: M. Burgess \& A. Gagnon (eds.), Comparative federalism and federation - competing traditions and future directions, Hemel Hempstead, 1993, pp. $117-137$

(7) J. Richardson, 'Policy-making in the European Union - a theoretical overview', in: J. Richardson (ed.), European Union - power and policy-making, London, 1996, pp. 3-21

(8) Over pleitcoalities zie P.A.Sabatier \& H.C.Jenkins-Smith (eds.), Policy change and learning, Boulder, 1993, pp. 211-235. Zie woor een breder overzicht ook P.A. Sabatier (ed.), Theories of the policy process - theoretical lenses on public policy, Boulder, 1999, en P. Hemminga, Het beleid inzake unieke regionale talen, Leeuwarden, 2000 , voor een interessante case-study.

(9) De beeldspraak van een 'layer cake' en een 'marble cake' zijn ook wel gebruikt woor een analyse van het Amerikaanse federale systeem. Vgl. W.H. Riker, "Federalism', in: F.L. Greenstein \& N.W. Polsby (eds.), Handbook of Political Science, Reading Mass, 1975, volume 5, pp. 93-172

(10) W. Wallace spreekt van 'government without statehood". In: H. Wallace \& W. Wallace (eds.), Policy-making in the European Union, Oxford, 2000, pp. 530-532

(11) Zie G. Edwards \& D. Spence (eds.), The European Commission. London, 1994

(12) P. van Buitenen, Strijd voor Europa - fraude in de Europese Commissie, Ten Have/Halewijck, 1999

(13) $\mathrm{Ph}$. Sherrington, The Council of Ministers - political authority in the European Union, London, 2000-12-15 
(14) J. Peterson \& E. Bomberg, Decision-making in the European Union, Houndmills; 1999

(15) G. Majone, "A European regulatory state?", in: J.Richardson (ed.), European Union-power and policy-making, London, 1996, pp. 263-277

(16) Dat er in het EU-beleid toch wel de nodige uitvoeringsproblemen bestaan, blijkt uit J. Richardson, 'Eroding EU-policies - implementation gaps, cheating and resteering', in: J. Richardson, supra, pp. 278-294

(17) Over de nationale motieven tot Europese samenwerking na de tweede wereldoorlog, zie o.a. S. George, Politics and policy in the European Union, Oxford, 1997, m.n. hoofdstukken 5,6,7

(18) B.J.S. Hoetjes, Het tussenbestuur en het buitenland - de Nederlandse prowincies en Europa, Den Haag, 2000

(19) R. Schobben, Politieke regio en Europese Unie, Delft, 2000; H. Vos, Regio's in de Europese Unie, Gent, 1998

(20) Zie bijvoorbeeld E.C. Page, Localism and centralism in Europe, Oxford, 1991; J. Loughlin a.o., Regional and local democracy in the European Union, Brussells, 1999

(21) Over de baten en lasten van de EU, zie M.-A. Wilssens, Wat kost ons Europa, Gent, 1999

(22) In de woorden van Wilssens (supra, p. 127-149): 'foefelen in Fraudopolis".

(23) Zie ook noot 18

(24) H. Kassim, B. Guy Peters \& V. Wright (eds.), The nationall co-ordination of EU policy, Oxford, 2000

(25) $\mathrm{Vgl}$. B. Thorhallson, The role of small states in the European Union, Aldershot, 2000

(26) R.A.W. Rhodes \& D. Marsh (eds.), Policy networks and policy communities, Oxford, $199 \mathrm{I}$, alsmede M.J. Smith, The politics of agricultural support in Britain - the development of the agricultural policy community, Aldershot, 1990, voor een case-study. Over de Europese instellingen: E.C. Page, People who run Europe, Oxford, 1997, alsmede het werk van de antropoloog M. Abelès.

(27) H. Wallace, in: H. Wallace \& W. Wallace (eds.), Policymaking in the European Union, Oxford, 2000 , pp. 31-32.

(28) Voor de lopende discussie in de EU zie Internationale Spectator, Den Haag, juni 2000, december 2000, alsmede C. Busse, 'Braucht Europa einen Kern? Zur gegenwartigen Diskussion um die Zukunft der europäischen Integration', in: Politik und Zeitgeschichte, november 2000, pp. 3-12

(29) Vgl. B.J.S. Hoetjes, Het Europees Parlement moet terug naar de burgers", in: Internationale Spectator, juni 2000, pp. 301-304 
(30) Vgl F. Fischer, Evalluating public policy, Chicago, 1995; R. Rose, Lessondrawing in public policy, Chatham N.J., 1993 


\section{ERRATA}

Pagina 10, regel 9: 'lagentaart' i.p.v. 'lagenmaat' Pagina 14, regel 6: 'bestuurslaag' i.p.v. 'bestuurslagen' Pagina 15, regel 24: 'opmerkelijke' i.p.v. 'opmerkelijk' Pagina 16, regel 13: 'uiteindelijke' vervalt Pagina 28, regel 10: 'nooit' i.p.v. 'noott' 